\title{
Integrated climate and land use change scenarios for California rangeland ecosystem services: wildlife habitat, soil carbon, and water supply
}

\author{
Kristin B. Byrd • Lorraine E. Flint • Pelayo Alvarez • \\ Clyde F. Casey $\cdot$ Benjamin M. Sleeter $\cdot$ Christopher E. Soulard $\cdot$ \\ Alan L. Flint • Terry L. Sohl
}

Received: 14 May 2014/Accepted: 16 January 2015/Published online: 5 February 2015

(C) The Author(s) 2015. This article is published with open access at Springerlink.com

\begin{abstract}
Context In addition to biodiversity conservation, California rangelands generate multiple ecosystem services including livestock production, drinking and irrigation water, and carbon sequestration. California rangeland ecosystems have experienced substantial conversion to residential land use and more intensive agriculture.

Objectives To understand the potential impacts to rangeland ecosystem services, we developed six spatially explicit $(250 \mathrm{~m})$ climate/land use change scenarios for the Central Valley of California and surrounding foothills consistent with three Intergovernmental Panel on Climate Change emission scenario narratives.
\end{abstract}

Electronic supplementary material The online version of this article (doi:10.1007/s10980-015-0159-7) contains supplementary material, which is available to authorized users.

K. B. Byrd $(\bowtie) \cdot$ B. M. Sleeter · C. E. Soulard Western Geographic Science Center, U.S. Geological Survey, 345 Middlefield Road, MS-531, Menlo Park, CA 94025, USA

e-mail: kbyrd@usgs.gov

L. E. Flint · A. L. Flint

California Water Science Center, U.S. Geological Survey, Placer Hall, 6000 J Street, Sacramento, CA 95819, USA

P. Alvarez

California Rangeland Conservation Coalition/Defenders of Wildlife, P. O. Box 73470, Davis, CA 95617, USA
Methods We quantified baseline and projected change in wildlife habitat, soil organic carbon (SOC), and water supply (recharge and runoff). For six case study watersheds we quantified the interactions of future development and changing climate on recharge, runoff and streamflow, and precipitation thresholds where dominant watershed hydrological processes shift through analysis of covariance.

Results The scenarios show that across the region, habitat loss is expected to occur predominantly in grasslands, primarily due to future development (up to a $37 \%$ decline by 2100), however habitat loss in priority conservation errors will likely be due to cropland and hay/pasture expansion (up to $40 \%$ by 2100). Grasslands in the region contain approximately 100 teragrams SOC in the top $20 \mathrm{~cm}$, and up to $39 \%$ of this SOC is subject to conversion by 2100 . In dryer periods recharge processes typically dominate runoff. Future development lowers the precipitation value at

\section{F. Casey}

Science and Decisions Center, U.S. Geological Survey, 12201 Sunrise Valley Drive, Reston,

Virginia 20192-0002, USA

T. L. Sohl

EROS Data Center, U.S. Geological Survey, 47914 252nd

Street, Sioux Falls, SD 57198-9801, USA 
which recharge processes dominate runoff, and combined with periods of drought, reduces the opportunity for recharge, especially on deep soils.

Conclusion Results support the need for climatesmart land use planning that takes recharge areas into account, which will provide opportunities for water storage in dry years. Given projections for agriculture, more modeling is needed on feedbacks between agricultural expansion on rangelands and water supply.

Keywords Rangeland · Ecosystem services · Land use/land cover change scenarios - Downscaled global climate models - Water supply - Soil carbon . Grassland $\cdot$ Climate change adaptation

\section{Introduction}

At 308 million ha, rangelands represent $31 \%$ of the total land area of the United States (Havstad et al. 2007). Rangelands comprise land on which vegetation is predominantly grasses, grass-like plants, forbs, or shrubs, and include natural grasslands, savannas, shrublands, many deserts, tundras, alpine communities, marshes, and meadows (Society for Range Management 1998). Given the scale and diversity of ecosystems that rangelands encompass, they have a substantial capacity to support biodiversity and provide ecosystem services, defined as human benefits provided by natural ecosystems (Millennium Ecosystem Assessment 2005). In California, rangelands are the largest land cover by area, covering over one half of the state. California annual grassland and hardwood woodlands, characterized as savannah with an overstory typically dominated by oaks (Quercus sp.), located primarily in California's Central Valley and surrounding foothills, provide over two-thirds of the forage for domestic livestock (California Department of Forestry and Fire Protection Fire and Resource Assessment Program 2003). While $43 \%$ of California rangelands are privately owned, within annual grasslands and hardwood woodlands, this percentage exceeds $80 \%$ (California Department of Forestry and Fire Protection Fire and Resource Assessment Program 2003). Rangelands provide habitat for plants, freshwater fish, wintering birds and waterfowl, invertebrates, and mammals. In particular, annual grasslands in the Central Valley support 75 species including 10 vertebrates, 14 invertebrates, and 51 plants that are listed as threatened or endangered under the Endangered Species Act (Jantz et al. 2007).

In addition to biodiversity conservation, rangelands generate multiple ecosystem services that carry considerable economic value. Though more commonly known for their provisioning ecosystem services, such as food and fiber, rangelands offer regulating services such as carbon sequestration, soil protection, and water quality and quantity (Havstad et al. 2007). Rangelands also produce cultural ecosystem services such as maintenance of scenic landscapes, tourism, cultural heritage, educational values, and recreation (Brunson and Huntsinger 2008).

In California annual grasslands, soil $\mathrm{C}$ pools in the top meter average $140 \mathrm{Mg} \mathrm{C} \mathrm{ha}^{-1}$ though the range in these pools span almost $200 \mathrm{Mg} \mathrm{C}^{-1}$ across sites, with higher values where woody vegetation is present (Silver et al. 2010). Conversion of rangelands to cropland or urban lands can release large quantities of carbon (Lal 2002; Potthoff et al. 2005; Chen et al. 2013). Annual rates of carbon sequestration in rangelands are low compared to other ecosystems, rarely exceeding $0.10 \mathrm{Mg} \mathrm{C} \mathrm{ha}^{-1}$ year $^{-1}$ (Follett et al. 2001). However, their vast land area and strong positive correlation between $\mathrm{C}$ sequestration and other ecosystem benefits demonstrate the need to protect existing C pools (Follett et al. 2001; Booker et al. 2013).

Unpredictable annual precipitation and an uncertain supply of fresh water are common for rangelands in the California Central Valley and surrounding foothills as characterized by their Mediterranean climate (Merenlender et al. 2008; Ash et al. 2012). This uncertainty in the timing and quantity of precipitation is likely to increase, according to climate change projections for California from global climate models (GCMs) (Shaw et al. 2009, 2011). Despite this uncertainty, rangelands can serve an important role in supplying water. The provision of water has been called "the ecosystem service that most directly links growing human populations to rangelands" (Havstad et al. 2007). Other ecosystem services are strongly affected by the quantity of water delivered to rangelands and how it is partitioned among processes of surface water flow, ground water recharge, evaporation, and transpiration. Many relatively static factors (topography, soils, and geology) and dynamic factors (climate, land 
management, and land use) interact to determine how this water is partitioned and how it will be delivered to competing consumers (Havstad et al. 2007). Water yield is difficult to measure and value, but the changing availability of water from rangeland watersheds needs to be quantified across multiple spatial scales and over long time horizons to ensure sustainable use (Scanlon et al. 2005; Havstad et al. 2007; Brown and MacLeod 2011; He and Hogue 2012).

Following land use trends in the western United States, California rangeland ecosystems have experienced substantial reductions due to conversion to residential land use and more intensive agriculture (Theobald 2005; Sleeter et al. 2011; Soulard and Wilson 2015; Cameron et al. 2014). Throughout California, grassland and shrubland area declined 513,100 ha between 1973 and 2000 (Sleeter et al. 2011). This loss of grassland and shrubland was prevalent in the foothills surrounding the Central Valley. Much of the gains in cropland in this region were due to the proliferation of high-value specialty crops such as vineyards and almonds at the expense of rangelands (Sleeter 2008; Sleeter et al. 2011).

Across the United States, disproportionate land use changes are expected to continue to occur on grasslands and shrublands for multiple future scenarios (Bierwagen et al. 2010). Mirroring this pattern, in the Central Valley, more than half of the land area is predicted to change by 2051 (Radeloff et al. 2012), with an increase in irrigated pasture and urban lands and a decrease in rangelands. Accelerating development of rangelands is projected to continue on lands surrounding the Central Valley as well (California Department of Forestry and Fire Protection Fire and Resource Assessment Program 2010). According to one urban growth scenario, future development will be concentrated in the Central Valley, the foothills of the Sierra Nevada, both sides of the Transverse Range and the San Francisco Bay area (U.S. Environmental Protection Agency 2009; Jongsomjit et al. 2013). While these projections address residential growth, in California, high-resolution future projections of rangeland conversion to intensive agriculture have not been available, despite its large impact on habitat availability and suitability (Jongsomjit et al. 2013).

Given the rapid land use changes occurring in California rangelands, an assessment of future impacts is necessary. Conducting such an assessment is challenging because they cover a large area, have mixed land ownership, and are ecologically diverse due to the high variability in annual precipitation (Weltz et al. 2011). Despite these challenges, there is a growing need to anticipate and identify drivers and patterns of large-scale rangeland conversion and improve models to project its consequences to ecosystem services, and the value of these services (Herrick et al. 2012).

In order to conduct an effective integrated assessment that addresses the impacts of climate change and land use-land cover change (LULC), it is critical that climate scenarios be matched with logically consistent LULC scenarios derived from the same storylines (Bierwagen et al. 2010). The Intergovernmental Panel on Climate Change (IPCC) Special Report on Emission Scenarios (SRES) and new IPCC Representative Concentration Pathways scenarios (Nakicenovic and Swart 2000; Moss et al. 2010; Vuuren et al. 2011) provide storylines of future greenhouse gas emissions. These storylines can serve as the basis for developing an integrated narrative of both climate and LULC change, and their combined impacts to a suite of biological resources and ecosystem services. Few studies have examined the combined effects of climate and land use change (de Chazal and Rounsevell 2009; Bierwagen et al. 2010). One example is a California study that found that for many bird populations, the potential impacts of development can be as great as or greater than the effects of climate change, and threats may vary in different combinations across the landscape (Jongsomjit et al. 2013).

We developed six integrated scenarios that represent alternative potential futures of climate/land use/ hydrological change for the California Rangeland Conservation Coalition (http://www.carangeland.org) (Rangeland Coalition) priority focus area for conservation and enhancement, which includes the Central Valley, surrounding foothills and Southern Interior Coast Range of California (Fig. 1a). This area includes 7.3 million hectares of rangelands, most of which are managed for livestock production. Three LULC change scenarios based on consistent storylines of the IPCC-SRES were each paired with two downscaled climate projections that represent future possible climates ranging from a warmer/dry future to a warm/wet future. We used these scenarios to quantify a baseline and possible changes in the provision of rangeland ecosystem services-wildlife habitat, soil carbon, and water supply. 


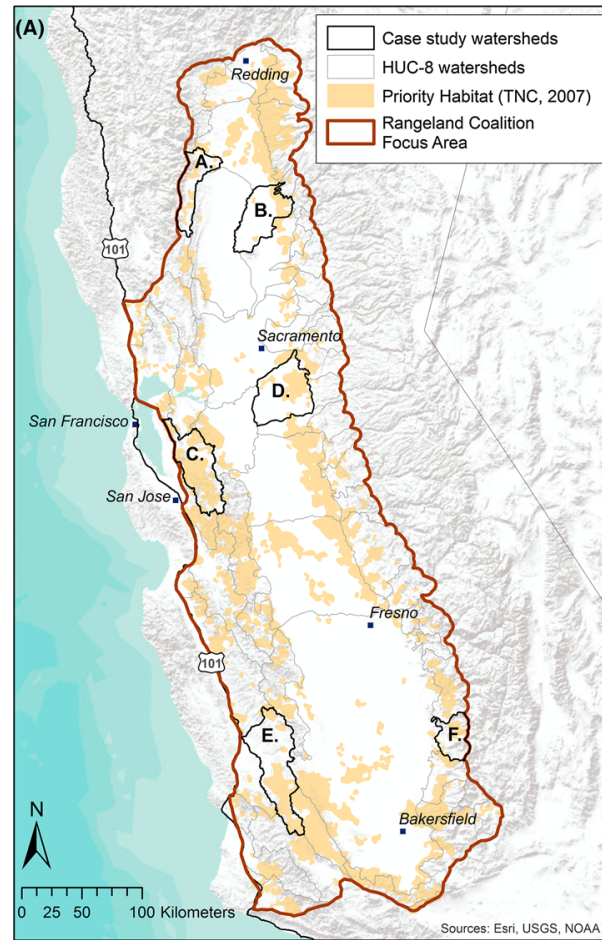

Fig. 1 a California Rangeland Conservation Coalition focus area, HUC-8 watershed boundaries clipped to focus area boundary, six case study watersheds, and priority habitat mapped by The Nature Conservancy (2007); b baseline 2010 land use-land cover (LULC) following the modified National Landcover Dataset classification for two level III EPA

Through the use of a probabilistic LULC change model, we produced maps of potential rangeland habitat changes as a result of changes in development, cropland, and hay/pasture. We identified baseline rangeland soil carbon stocks, and the quantity of soil carbon potentially altered by land use changes. Given downscaled climate projections, we projected the provision of water within the Rangeland Coalition focus area through a hydrologic process model that partitions water into evapotranspiration, recharge, and runoff. We identified water-wildlife hotspots of change, where loss of water and habitat coincide. We follow with an analysis of the separate and combined effects of urban development and changing climate on water availability and streamflow. Results are presented at the scale of the Rangeland Coalition focus area map and for six case study watersheds. An outreach program for land owners and land managers ecoregions: California Central Valley and Chaparral and Oak Woodlands. Priority habitat is defined as rangeland habitat in unprotected critical priority conservation areas mapped in the Rangeland Coalition focus area map (The Nature Conservancy 2007). LULC in the ecoregions was used to represent LULC for the focus area

has been developed by Defenders of Wildlife to communicate how results can be applied to conservation and land management decisions.

\section{Methods}

Study area

The Rangeland Coalition focus area boundaries extend to the higher elevation distribution limits of blue oak (Quercus douglasii), California's dominant oak species by total area (Gaman and Firman 2006). To the east and northwest, the boundary ends at the transition between blue oak woodlands and montane hardwood or conifer forest, while the western boundary runs along Highway 101 (Fig. 1a) (The Nature Conservancy 2007). Other important plant 
communities in the region include vernal pools (seasonally flooded depression wetlands with a hardpan subsurface that limits drainage) and riparian forest dominated by western cottonwood (Populus fremontii), valley oaks (Quercus lobata), and western sycamore (Platanus racemosa). Common soil orders on annual grasslands include Entisols and Alfisols (Garrison et al. 1977). Annual precipitation is highest in the north [Redding, $960 \mathrm{~mm}$ (38 in.)], and reaches a minimum in the southern San Joaquin Valley [Bakersfield, $150 \mathrm{~mm}$ (6 in.)] (Major 1977).

Land use-land cover change scenarios

Future potential LULC change was based on a set of scenarios from three IPCC-SRES storylines (Nakicenovic and Swart 2000): A2, A1B, and B1 that were developed as part of the United States Geological Survey's (USGS) national carbon sequestration assessment of ecosystem carbon stocks, carbon sequestration, and greenhouse gas fluxes under present conditions and future scenarios (hereafter referred to as the USGS assessment) (Sleeter et al. 2012; Zhu and Reed 2012). The three scenarios differ by socioeconomic drivers that include population, economic development, rate of technological innovation, changes in the energy sector, the relative importance of environmental protection, and the degree of globalization (Appendix 1 in ESM).

To develop LULC change scenarios that were logically consistent with SRES storylines, Sleeter et al. (2012) used projected national LULC change data from the Integrated Model to Assess the Global Environment (IMAGE) (Strengers et al. 2004) that was modified and allocated to EPA Level III ecoregions according to land use histories from the USGS Land Cover Trends project (Loveland et al. 2002), as well as expert knowledge. For this study, we used scenarios developed for EPA Level III ecoregions Central California Valley and the Chaparral and Oak Woodlands (U.S. Environmental Protection Agency 2013), which overlap $92 \%$ of the Rangeland Coalition focus area and fully contain the six case study watersheds (Fig. 1b).

The LULC classification scheme for the scenarios closely follows the National Land Cover Database (NLCD) (Vogelmann et al. 2001; Homer et al. 2007) and includes broad classes such as agriculture (further divided into cropland and hay/pasture), development, grassland, shrubland, deciduous, evergreen and mixed forest, herbaceous wetlands, and woody wetlands. The agriculture classes include land used for the production of food or fiber, including cultivated and uncultivated croplands, orchards, vineyards, irrigated hay, pasture lands, and confined livestock operations. The developed class includes a combination of development density classes. The scenarios provide demand, or area of land allocated to each LULC class over time. The demand for developed land was based on population projections similar to the California Department of Finance projections (State of California Department of Finance 2013). The Department of Finance population projection for 2060 (latest year available) is 52.7 million people. The A1B and B1 projections for California are 47.8 million and the $\mathrm{A} 2$ projection is 53.6 million. By 2100, A1B and B1 population projections for California level at 55.3 million, and the $\mathrm{A} 2$ population grows to 75.3 million people.

To further distinguish scenarios, we incorporated future conservation scenarios into LULC change modeling. Conservation scenarios were based on unprotected critical and important priority conservation areas mapped in the Rangeland Coalition focus area. These areas were defined as privately owned rangelands that have high biodiversity value (The Nature Conservancy 2007). For the conservation scenario (B1), we created a map of one million acres (404,686 ha) of land located in critical priority conservation areas near existing protected lands within the Rangeland Coalition boundary, where no future land use change would occur. This land area was determined based on existing conservation goals (California Rangeland Trust, Meredith Kupferman personal communication, March, 2012) and historical trends of conservation land protection (GreenInfo Network 2011; U.S. Endowment for Forestry and Communities 2011). In the A1B scenario, which follows a mixed use-based conservation storyline, we assumed conservation of 500,000 acres (202,343 ha) of land in important or critical priority conservation areas near population centers. In the A2 scenario, we did not identify any land explicitly for conservation. To generate maps of future conservation, units of conservation were set at 1056 ha to simulate a typical size of a conservation easement acquisition (California Rangeland Trust, Meredith Kupferman personal communication, March, 2012). 
Future climate projections

A selection of future climate projections included an ensemble of models from the World Climate Research Programme's Coupled Model Intercomparison Project phase 3 (CMIP3) multi-model dataset (Meehl et al. 2007). In California, climate projections based on the same emission scenarios vary greatly by amount of precipitation. As a result, each LULC change scenario was matched with two climate projections with corresponding IPCC-SRES storylines (A2, A1B, and B1) to represent a range of representative future climate projections for California. For each scenario, one climate projection represented a warm, wet future and the other represented a warmer, dry future (Appendix 1 in ESM). Projections with modeled minimum and maximum air temperature were selected because those parameters are considered important determinants of vegetation distribution. Based on the need for these temperature parameters, we selected the PCM (warm, wet future; U.S. National Center for Atmospheric Research Parallel Climate Model) and GFDL (warmer, dry future; U.S. National Oceanic and Atmospheric Administration Geophysical Fluid Dynamics Laboratory) models for the A2 and B1 scenarios, and we selected the CSIRO (warm, wet future; Australia CSIRO Atmospheric Research) and MIROC (warmer, dry future; Japan Center for Climate System Research, University of Tokyo) models for the A1B scenario (Appendix 1 in ESM). Monthly estimates of precipitation and maximum and minimum air temperature were downscaled using a gradientinverse-distance squared methodology to 270-m spatial resolution (Flint and Flint 2012) for application to the FOREcasting SCEnarios LULC change model (FORE-SCE) and the Basin Characterization Model (BCM), a regional water balance model (Flint et al. 2013).

\section{The Basin Characterization Model}

The BCM is a regional water balance model that has been developed for California for the historical period (1896-2010) and for 18 future projections (Flint and Flint 2014). The California BCM applies gridded climate data [historical climate from PRISM (Daly et al. 2008) or future climate projections] and a rigorous calculation of hourly potential evapotranspiration (PET) using solar radiation and topographic shading to provide energy forcings to calculate monthly changes in snowpack, snowmelt, soil moisture, climatic water deficit, recharge, and runoff for all 270-m grid cells. Post-processing is done using the accumulation of recharge and runoff into monthly time series for any basin to calculate basin discharge (streamflow). Calibration is done using the combination of recharge and runoff from all grid cells upstream of stream gages to calculate streamflow and match measured streamflow (Flint et al. 2013). Climatic water deficit was used as an input to the FORE-SCE LULC change model to control the distribution of a set of LULC types, while recharge, runoff, and streamflow variables were analyzed to assess changes to water supply on rangelands.

Land use-land cover change maps

The FORE-SCE LULC change model was used to distribute the demand for future regional LULC change on the landscape for each scenario (Sohl et al. 2012, 2014). Demand was allocated spatially according to probability of occurrence raster datasets (suitability surfaces). These datasets were generated for each LULC class in each ecoregion through a stepwise logistic regression approach in SAS 9.0 (SAS Institute Inc. 2002-2010) that related present-day locations of each LULC class to several biophysical and socioeconomic characteristics of the landscape, such as slope, elevation, soil carbon, climate, and distance to roads and cites (Appendix 2 in ESM). All input variables, including downscaled climate and $\mathrm{BCM}$ variables, were resampled to a consistent $250-\mathrm{m}$ resolution. Model outputs are 250-m maps of LULC change generated yearly from 2006 to 2100 .

\section{Ecosystem services modeling}

Changes in ecosystem services were presented at the scale of the Rangeland Coalition focus area and for six case study watersheds. Watershed boundaries within the focus area were based on the eight-digit watershed boundary dataset (HUC-8) (http://water.usgs.gov/ GIS/huc.html). For watersheds that intersected the focus area, only the watershed portion that fell within the focus area was used as a unit of analysis. Of the 70 watersheds in the focus area, six watersheds (Upper Stony Creek, Lower Butte, Lower Cosumnes-Mokelumne, Alameda Creek, Estrella River, and Upper 
Table 1 Matrix table of ecosystem services metrics by spatial extent

\begin{tabular}{|c|c|}
\hline Rangeland Coalition focus area & Case study watersheds ${ }^{\mathrm{a}}$ \\
\hline \multicolumn{2}{|l|}{ Habitat } \\
\hline Baseline rangeland habitat & Baseline rangeland habitat \\
\hline Area and $\%$ change rangeland habitat & Area and $\%$ change rangeland habitat \\
\hline \multicolumn{2}{|l|}{ Area and $\%$ change priority habitat } \\
\hline \multicolumn{2}{|c|}{$\%$ change in priority habitat, as proportion of each $\mathrm{HUC}-8$ watershed } \\
\hline \multicolumn{2}{|l|}{ Carbon } \\
\hline $\begin{array}{l}\text { Baseline soil organic carbon (SOC) stocks in all rangeland } \\
\text { habitats and in grasslands }\end{array}$ & $\begin{array}{l}\text { Baseline soil organic carbon (SOC) stocks in } \\
\text { all rangeland habitats and in grasslands }\end{array}$ \\
\hline $\begin{array}{l}\text { SOC stocks in all rangeland habitats and in grasslands } \\
\text { subject to land use change }\end{array}$ & $\begin{array}{l}\text { SOC stocks in all rangeland habitats and } \\
\text { in grasslands subject to land use change }\end{array}$ \\
\hline \multicolumn{2}{|l|}{ Water supply } \\
\hline Baseline 30-year average recharge and runoff & Baseline 30 -year average recharge and runoff \\
\hline \multirow[t]{2}{*}{$\begin{array}{l}\% \text { change in recharge and runoff for three } 30 \text {-year } \\
\text { climate periods, averaged by each HUC- } 8 \text { watershed }\end{array}$} & $\begin{array}{l}\text { Annual recharge and runoff with increasing } \\
\text { urban development (urban watersheds, } \\
\text { GFDL A2 scenario only) }\end{array}$ \\
\hline & $\begin{array}{l}\text { Recharge, runoff, and streamflow } \\
\text { response to urban development and precipitation }\end{array}$ \\
\hline
\end{tabular}

For habitat and carbon, all metrics were calculated for each IPCC-SRES scenario (A2, A1B, and B1). For water supply, all metrics except annual recharge and runoff with urbanization were calculated for each climate projection (a warmer, dry and a warm, wet projection for each IPCC-SRES scenario, six in total). The baseline year for habitat and carbon is defined as 2010 . The baseline time period for water supply is the 1981-2010 climate period. Rangeland habitat in the land use-land cover (LULC) maps is defined as areas mapped as grassland, shrubland, forest, woody wetland, or herbaceous wetland. Priority habitat is defined as rangeland habitat in unprotected critical priority conservation areas mapped in the Rangeland Coalition focus area (The Nature Conservancy 2007)

${ }^{a}$ Case study watersheds include three urban-dominated watersheds (Lower Butte, Cosumnes, and Alameda Creek) and three agriculture-dominated watersheds (Upper Stony, Estrella, and Upper Tule)

Tule) (Fig. 1a) were selected for more detailed analysis on changes in wildlife habitat, carbon stocks, and water supply. These watersheds contain critical priority conservation areas and experienced significant increase in either development or agriculture in the scenarios. A summary of ecosystem services metrics by scale of analysis is provided in Table 1 .

\section{Habitat}

We defined baseline rangeland habitat as the area classified as either grassland, shrubland, forest, woody wetland, or herbaceous wetland in the year 2010 modified NLCD map generated from the FORE-SCE model. In this region, forest is typically oak woodland, woody wetland is predominantly riparian forest, and herbeceous wetlands include vernal pools. Baseline priority habitat is defined as rangeland habitat in unprotected critical priority conservation areas mapped in the Rangeland Coalition focus area (The Nature Conservancy 2007).

At the larger focus area scale, for baseline rangeland habitats and for priority habitats, we calculated change in area and percent change of each habitat type from 2010 to each decade from 2020 to 2100 for each LULC scenario. We repeated this analysis for baseline rangeland habitats in the case study watersheds. Change in habitat was defined to occur if areas mapped as either forest, grassland, shrubland, or wetland in 2010 were converted to one of the following classes: developed, logging, mining, cropland, or hay/pasture.

In addition, for all HUC-8 watersheds in the focus area, we calculated the percent change in the proportion of watershed area that contains priority habitat from 2010 to three future years $(2040,2070$, and 2100) for the three LULC scenarios. These results were combined with projections of percent change in water 
supply (Water supply section) to generate a focus areawide water-wildlife hotspots of change map.

\section{Soil carbon}

To quantify baseline soil organic carbon (SOC) stocks within the Rangeland Coalition focus area and separately for the case study watersheds, we used the top $20 \mathrm{~cm}$ SOC output variable from the USGS assessment (Liu et al. 2012; Zhu and Reed 2012). Baseline SOC was derived from the U.S. Department of Agriculture (USDA) Soil Survey Geographic Database (SSURGO) at 250-m resolution to generate a map of ecologically active stocks of soil organic carbon (SOC) near the surface (0-20 cm depths) (Bliss 2003).

To identify the SOC stocks potential altered by land use change, we quantified SOC on rangeland habitats in the focus area and in each case study watershed that were converted by 2100 for each LULC scenario. We report SOC stocks on all converted rangeland habitats and for grassland in particular, the dominant habitat type in the region by area.

\section{Water supply}

Water supply is defined as the combination of recharge and runoff to a watershed, and can be utilized on the basis of any established infrastructure, whether groundwater wells, reservoirs, streams, or riparian zones. The BCM was run with the six climate projections, two projections for each of three LULC change scenarios. We calculated baseline recharge and runoff as the 30-year average of water years for the climate period 1981-2010 averaged by the focus area and by watershed areas. We then calculated the percent change in recharge and runoff for three 30-year future climate periods: 2010-2039, 2040-2069, and 2070-2099. Percent change values were calculated for all HUC- 8 watersheds in the focus area for use in the focus area-wide water-wildlife hotspots of change map.

\section{Integrated urban development/climate effects on water supply}

To explore the potential consequences of future urban development and changing climate on water supply, we ran the BCM an additional time for the GFDL A2 warmer, dry projection yearly from 2002 to 2099 for the three urbanized case study watersheds: Alameda Creek, Cosumnes, and Lower Butte. In this case, at 10-year intervals from 2010 to 2099, all locations where development was present in the FORE-SCE model, outputs were assumed to have a soil depth of $0.1 \mathrm{~m}$ to reduce the storage capacity and simulate urbanized landscapes. In contrast, the baseline BCM model runs used original soil depth values based on SSURGO datasets (Natural Resources Conservation Service 2006). Recharge and runoff volumes for the two cases (future urbanization and no future urbanization) were plotted to view yearly differences in these values.

In addition, for each of the six climate projections, for all six case study watersheds, we selected three 4-year time periods (2037-2040, 2067-2070, and 2096-2099) and one baseline period (2003-2006) to further test the effects of future development and climate on water supply. For each of the projections and for each of the listed years, the BCM was re-run simulating urban landscapes as described above. For each year, for the urban and non-urban simulations, water year totals for runoff, recharge, and streamflow were calculated. For the baseline and three future time periods, we then calculated the 4-year average recharge, runoff, streamflow, and precipitation for both simulations, urban and non-urban for each scenario.

These 4-year averages from each model run were pooled into a dataset to generate a range of precipitation and hydrological response variables for two cases - future urbanization and no future urbanization. This dataset was used in an analysis of covariance (ANCOVA) (Quinn and Keough 2002) to test how each dependent variable (runoff, recharge, and streamflow) varied with precipitation for the two cases within each case study watershed. We used ANCOVA to test the effect of urbanization on these relationships and to compare the regression lines between the urban and non-urban cases. Statistical analyses were conducted in Stata SE 12.1 (StataCorp LP 1985-2011). We tested two null hypotheses. If the first hypothesis (1) the slopes of the regression lines are all the same, was not rejected, we tested the second null hypothesis: (2) the Y-intercepts of the regression lines are all the same. Different slopes would occur if future development is related to a change in the rate of hydrologic response with respect to precipitation, while different intercepts would occur if mean hydrological response is 
Table 2 Baseline ecosystem service values for all rangeland habitat, grasslands, soil organic carbon (top $20 \mathrm{~cm}$ ) in all rangeland habitat and grassland, and water supply for six case study watersheds and the California Rangeland Conservation Coalition focus area

\begin{tabular}{|c|c|c|c|c|c|c|c|}
\hline Watershed & Area $\left(\mathrm{km}^{2}\right)$ & $\begin{array}{l}\text { Rangeland } \\
\text { habitat } \\
\left(\mathrm{km}^{2}\right)\end{array}$ & $\begin{array}{l}\text { Grassland } \\
\text { habitat } \\
\left(\mathrm{km}^{2}\right)\end{array}$ & $\begin{array}{l}\text { Total } \\
\text { rangeland } \\
\text { habitat SOC } \\
(\mathrm{Tg}, \text { top } 20 \mathrm{~cm})\end{array}$ & $\begin{array}{l}\text { Total } \\
\text { grassland } \\
\text { habitat SOC } \\
(\mathrm{Tg}, \text { top } 20 \mathrm{~cm})\end{array}$ & $\begin{array}{l}\text { Recharge } \\
1981-2010 \\
\left(10 \times 6 \mathrm{~m}^{3}\right)\end{array}$ & $\begin{array}{l}\text { Runoff } \\
1981-2010 \\
\left(10 \times 6 \mathrm{~m}^{3}\right)\end{array}$ \\
\hline Alameda Creek & 1,789 & 1,571 & 832 & 3.95 & 2.26 & 214 & 175 \\
\hline Cosumnes & 1,926 & 990 & 819 & 2.35 & 2.04 & 199 & 75 \\
\hline Estrella & 2,464 & 2,145 & 1,707 & 6.85 & 5.75 & 120 & 58 \\
\hline Lower Butte & 1,552 & 448 & 268 & 1.74 & 0.85 & 244 & 96 \\
\hline Upper Stony & 1,061 & 1,476 & 647 & 2.42 & 1.41 & 149 & 179 \\
\hline Upper Tule & 820 & 607 & 175 & 1.21 & 0.45 & 71 & 136 \\
\hline Focus Area & 113,221 & 59,859 & 34,354 & 161.44 & 99.77 & 9,253 & 9,814 \\
\hline
\end{tabular}

The watersheds are located within the focus area. Rangeland habitat in the land use-land cover (LULC) maps is defined as areas mapped as grassland, shrubland, forest, woody wetland, or herbaceous wetland

significantly different between the urban and nonurban cases across a range of precipitation values. We tested for the assumptions of ANCOVA, including normality and equal variance of the error terms, and independence of the covariate (precipitation) and the treatment effect (urbanization). Based on plots of residuals and the skewness/kurtosis test of normality, the assumptions for normality and equal variance were met.

\section{Results}

Habitat

Baseline rangeland habitat in the focus area is approximately $59,859 \mathrm{~km}^{2}$ (Table 2). Overall, across the focus area from 2010 to 2100 , developed lands increase between $127 \%$ in the B1 scenario and $244 \%$ in the A2 scenario (Table 3). Cropland and hay/ pasture increase the most in the A1B scenario (a $30 \%$ increase). In the focus area, the greatest area of land conversion occurs due to new development $\left(11,896 \mathrm{~km}^{2}\right.$, A2 scenario). Grassland, shrubland, and herbaceous wetlands experience the greatest percent loss in each scenario (e.g., 37, 38, and $57 \%$ loss, respectively, A2 scenario), and grassland experiences the greatest area loss in each scenario (7,866-1,280 km²) (Table 3; Fig. 2).

In priority habitats within the focus area, developed lands increase by $700 \%$ in the A2 scenario $\left(1,469 \mathrm{~km}^{2}\right)$ but the greatest area of land conversion occurs due to new cropland $\left(2,716 \mathrm{~km}^{2}\right)$ (Table 4). Hay/pasture increases by $1,223 \mathrm{~km}^{2}$ in the A2 scenario as well. In these priority habitats, grassland, shrubland, and herbaceous wetlands experience the greatest percent loss. $90 \%$ of herbaceous wetlands are lost in the A2 scenario though they increase by $39 \%$ in the B1 scenario, as this scenario incorporates wetland restoration in its narrative. Again, grassland experiences the greatest loss by area (up to $4,472 \mathrm{~km}^{2}, \mathrm{~A} 2$ scenario) (Table 4; Fig. 2).

The six case study watersheds can be divided into two categories - those where future urban development is prevalent (Alameda Creek, Lower Cosumnes, and Lower Butte) and those where future cropland and hay/pasture are prevalent (Upper Stony, Estrella, and Upper Tule). In the Alameda Creek watershed, almost $300 \%$ increase in development in the A2 scenario leads to a loss of cropland, hay/pasture lands as well as grassland, shrubland, and wetland habitats (Table 5). In Lower Cosumnes and Lower Butte watersheds, this increase in development does not lead to a substantial loss in cropland, but results in a shift in the location of cropland further east into rangelands, leading to the pattern of loss in grassland, shrubland, and herbaceous wetlands seen throughout the focus area. Across all case study watersheds, the greatest habitat loss by area occurs in grasslands, with the most conversion occurring in the Estrella River watershed at $810 \mathrm{~km}^{2}$ in the A2 scenario, primarily due to increased agriculture (Table 5; Fig. 3). 
Table 3 Land use-land cover change by scenario and year within the California Rangeland Conservation Coalition focus area

\begin{tabular}{|c|c|c|c|c|c|c|c|c|}
\hline Focus area & $\begin{array}{l}\text { Grassland } \\
\left(\mathrm{km}^{2}\right)\end{array}$ & $\begin{array}{l}\text { Shrubland } \\
\left(\mathrm{km}^{2}\right)\end{array}$ & $\begin{array}{l}\text { Forest } \\
\left(\mathrm{km}^{2}\right)\end{array}$ & $\begin{array}{l}\text { Herbaceous } \\
\text { wetland }\left(\mathrm{km}^{2}\right)\end{array}$ & $\begin{array}{l}\text { Woody } \\
\text { wetland }\left(\mathrm{km}^{2}\right)\end{array}$ & $\begin{array}{l}\text { Developed } \\
\left(\mathrm{km}^{2}\right)\end{array}$ & $\begin{array}{l}\text { Cropland } \\
\left(\mathrm{km}^{2}\right)\end{array}$ & $\begin{array}{l}\text { Hay/pasture } \\
\left(\mathrm{km}^{2}\right)\end{array}$ \\
\hline \multicolumn{9}{|l|}{ A2 scenario } \\
\hline 2010 & 34,354 & 8,143 & 16,101 & 692 & 112 & 4,876 & 27,326 & 9,965 \\
\hline 2100 & 21,533 & 5,078 & 15,996 & 298 & 108 & 16,772 & 30,616 & 11,580 \\
\hline$\%$ change & -37 & -38 & -1 & -57 & -4 & 244 & 12 & 16 \\
\hline \multicolumn{9}{|c|}{ A1B scenario } \\
\hline 2010 & 34,692 & 8,193 & 16,104 & 757 & 113 & 5,049 & 26,753 & 9,876 \\
\hline 2100 & 22,662 & 5,673 & 16,015 & 392 & 109 & 14,750 & 30,909 & 11,286 \\
\hline$\%$ change & -35 & -31 & -1 & -48 & -3 & 192 & 16 & 14 \\
\hline \multicolumn{9}{|l|}{ B1 scenario } \\
\hline 2010 & 34,733 & 8,190 & 16,107 & 835 & 114 & 4,810 & 26,840 & 9,898 \\
\hline 2100 & 26,867 & 6,459 & 16,121 & 1,393 & 118 & 10,906 & 29,535 & 10,178 \\
\hline$\%$ change & -23 & -21 & 0 & 67 & 4 & 127 & 10 & 3 \\
\hline
\end{tabular}

Rangeland habitat in the land use-land cover (LULC) maps is defined as areas mapped as grassland, shrubland, forest, woody wetland, or herbaceous wetland

(A) A2 Scenario

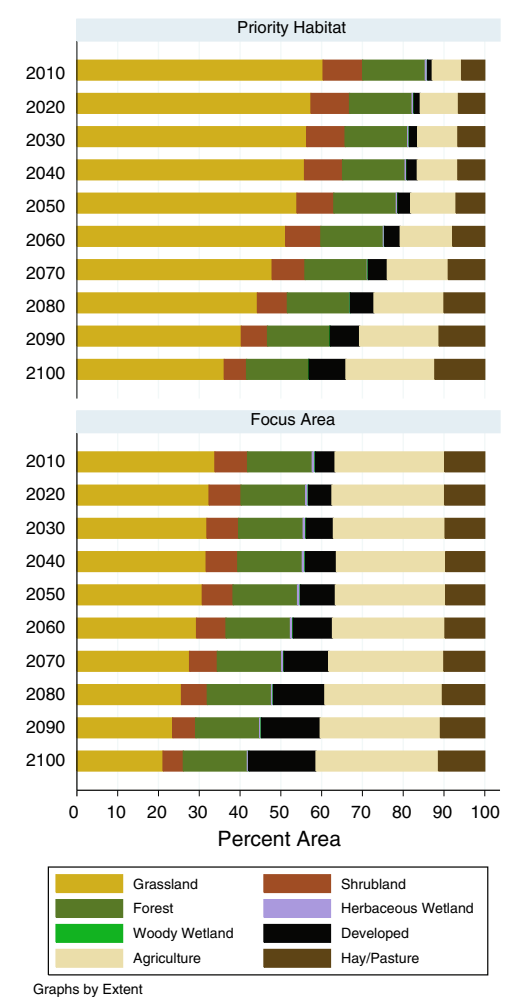

(B) A1B Scenario
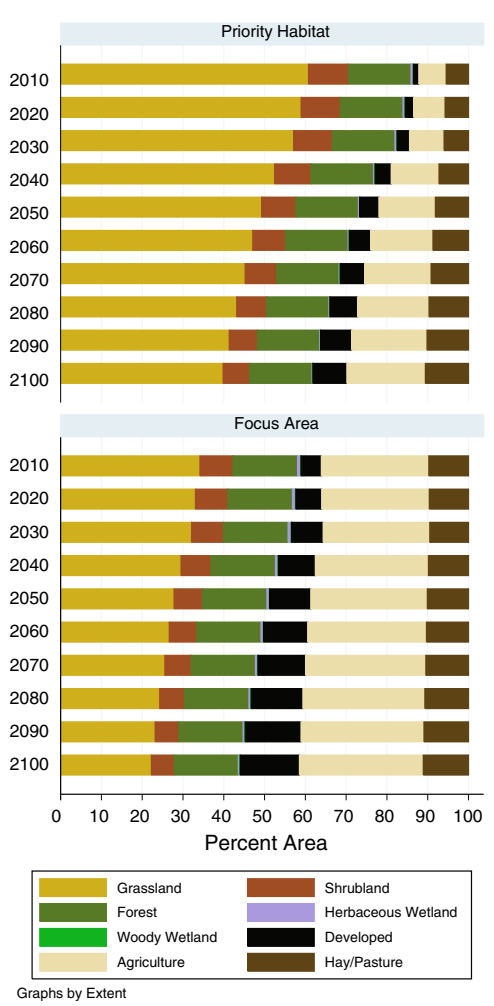

(C) B1 Scenario

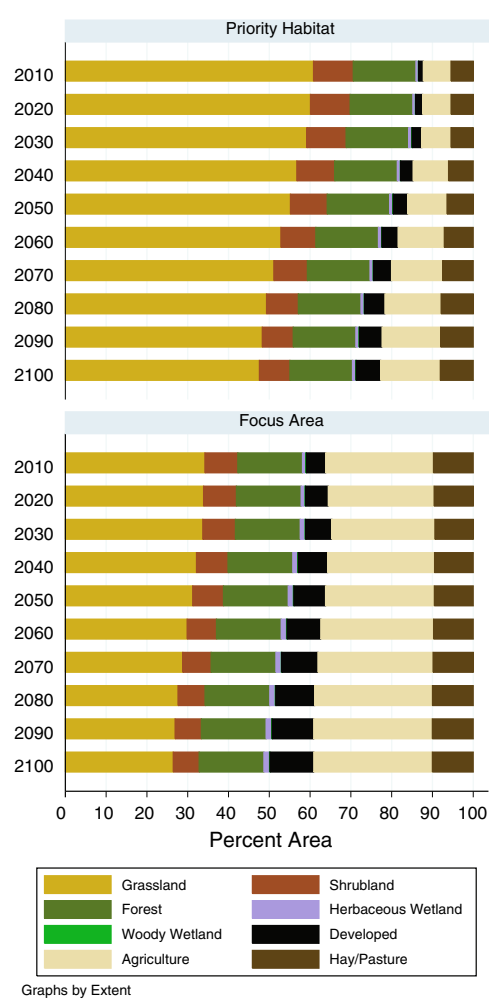

Fig. 2 Land use and land cover change by scenario and year for priority habitats and the California Rangeland Conservation Coalition Focus Area as a percentage of total area for scenarios $A 2$ (a), $A 1 B(\mathbf{b})$, and $B 1$ (c). Rangeland habitat is defined as areas mapped as grassland, shrubland, forest, woody wetland, or herbaceous wetland. Priority habitat is defined as rangeland habitat in unprotected critical priority conservation areas mapped in the Rangeland Coalition focus area map (The Nature Conservancy 2007) 
Table 4 Land use-land cover change by scenario and year within all priority habitats in the California Rangeland Conservation Coalition focus area

\begin{tabular}{|c|c|c|c|c|c|c|c|c|}
\hline Priority habitat & $\begin{array}{l}\text { Grassland } \\
\left(\mathrm{km}^{2}\right)\end{array}$ & $\begin{array}{l}\text { Shrubland } \\
\left(\mathrm{km}^{2}\right)\end{array}$ & $\begin{array}{l}\text { Forest } \\
\left(\mathrm{km}^{2}\right)\end{array}$ & $\begin{array}{l}\text { Herbaceous } \\
\text { wetland }\left(\mathrm{km}^{2}\right)\end{array}$ & $\begin{array}{l}\text { Woody } \\
\text { wetland }\left(\mathrm{km}^{2}\right)\end{array}$ & $\begin{array}{l}\text { Developed } \\
\left(\mathrm{km}^{2}\right)\end{array}$ & $\begin{array}{l}\text { Cropland } \\
\left(\mathrm{km}^{2}\right)\end{array}$ & $\begin{array}{l}\text { Hay/pasture } \\
\left(\mathrm{km}^{2}\right)\end{array}$ \\
\hline \multicolumn{9}{|l|}{ A2 scenario } \\
\hline 2010 & 11,185 & 1,798 & 2,847 & 94 & 11 & 210 & 1,334 & 1,054 \\
\hline 2100 & 6,713 & 1,016 & 2,828 & 10 & 11 & 1,679 & 4,050 & 2,277 \\
\hline$\%$ change & -40 & -44 & -1 & -90 & -6 & 700 & 204 & 116 \\
\hline \multicolumn{9}{|l|}{ A1B scenario } \\
\hline 2010 & 11,290 & 1,814 & 2,854 & 101 & 11 & 243 & 1,247 & 1,016 \\
\hline 2100 & 7,412 & 1,218 & 2,839 & 27 & 10 & 1,548 & 3,582 & 1,967 \\
\hline$\%$ change & -34 & -33 & -1 & -73 & -7 & 537 & 187 & 94 \\
\hline \multicolumn{9}{|l|}{ B1 scenario } \\
\hline 2010 & 11,275 & 1,807 & 2,849 & 109 & 11 & 213 & 1,260 & 1,009 \\
\hline 2100 & 8,831 & 1,387 & 2,849 & 152 & 11 & 1,117 & 2,715 & 1,499 \\
\hline$\%$ change & -22 & -23 & 0 & 39 & 2 & 424 & 116 & 49 \\
\hline
\end{tabular}

Rangeland habitat in the land use-land cover (LULC) maps is defined as areas mapped as grassland, shrubland, forest, woody wetland, or herbaceous wetland. Priority habitat is defined as rangeland habitat in unprotected critical priority conservation areas mapped in the Rangeland Coalition focus area map (The Nature Conservancy 2007)

Across the entire focus area, the greatest proportion of priority habitat loss by 2100 is found in the Carrizo Plain watershed at $16.7 \%$ under the A2 scenario. Earlier in the century, by 2040, the Suisun Bay watershed exhibits the greatest change in priority habitat $(-6 \%)$ in the A1B scenario. The Suisun Bay watershed also experiences the greatest loss in habitat $(-7.6 \%)$ compared to other watersheds by 2100 under the B1 conservation scenario (Fig. 4).

\section{Soil carbon}

In the focus area, average baseline SOC pools in the top $20 \mathrm{~cm}$ are $161.4 \mathrm{Tg} \mathrm{C}$ in all rangeland habitats and 99.8 Tg C in grassland habitats. Following patterns of rangeland conversion in the LULC scenarios, $29 \%$ of rangeland habitat SOC and $39 \%$ of grassland SOC in the focus area are potentially altered under the A2 scenario (Table 6). In the A2 scenario, the Lower Butte watershed experiences the greatest potential rangeland soil disturbance compared to other case study watersheds (61\% converted). However, this watershed experiences a $49 \%$ gain in rangeland SOC in the B1 scenario due to restoration actions incorporated into the scenario's storyline. When considering grassland SOC only, the Lower Butte watershed experiences the greatest amount of SOC disturbance across all scenarios, with $68 \%$ subject to conversion to development or agriculture in the A2 scenario (Table 6).

Water supply

Baseline water supply in the Rangeland Coalition focus area for the historical 30-year climate period is an average of 9,253 million $\mathrm{m}^{3}$ year $^{-1}$ in recharge and 9,814 million $^{3}$ year $^{-1}$ in runoff (Table 2 ). The case study watershed with the most combined baseline recharge and runoff is Alameda Creek with 389 million $\mathrm{m}^{3}$ year $^{-1}$.

With the high variation in precipitation projections among climate models, outcomes for watersheds in the focus area could tend toward increases or decreases in water supply depending on the climate model. Outcomes are highly uncertain for the Carrizo Plain watershed, for example. At minimum, a $19 \%$ loss in water supply is projected for the 2070-2099 period under the GFDL A2 (warmer/dry) projection though losses could reach $85 \%$ under the very dry MIROC A1B projection. The CSIRO A1B projection shows an increase in water supply of $88 \%$.

When change in water supply is combined with change in priority habitat, water-wildlife hotspots of change in both variables emerge across the focus area. For the warmer, dry climate projections, four 
Table 5 Land use-land cover (LULC) change by year in case study watersheds for the A2 LULC change scenario

\begin{tabular}{|c|c|c|c|c|c|c|c|c|}
\hline & $\begin{array}{l}\text { Grassland } \\
\left(\mathrm{km}^{2}\right)\end{array}$ & $\begin{array}{l}\text { Shrubland } \\
\left(\mathrm{km}^{2}\right)\end{array}$ & $\begin{array}{l}\text { Forest } \\
\left(\mathrm{km}^{2}\right)\end{array}$ & $\begin{array}{l}\text { Herbaceous } \\
\text { wetland }\left(\mathrm{km}^{2}\right)\end{array}$ & $\begin{array}{l}\text { Woody } \\
\text { wetland }\left(\mathrm{km}^{2}\right)\end{array}$ & $\begin{array}{l}\text { Developed } \\
\left(\mathrm{km}^{2}\right)\end{array}$ & $\begin{array}{l}\text { Cropland } \\
\left(\mathrm{km}^{2}\right)\end{array}$ & $\begin{array}{l}\text { Hay/pasture } \\
\left(\mathrm{km}^{2}\right)\end{array}$ \\
\hline \multicolumn{9}{|c|}{ Alameda Creek } \\
\hline 2010 & 832.31 & 195.44 & 543.06 & 0.38 & 0.13 & 157.38 & 21.88 & 35.31 \\
\hline 2100 & 458.63 & 159.25 & 536.81 & 0.19 & 0.06 & 623.06 & 7.75 & 1.75 \\
\hline$\%$ change & -45 & -19 & -1 & -50 & -50 & 296 & -65 & -95 \\
\hline \multicolumn{9}{|l|}{ Cosumnes } \\
\hline 2010 & 819.56 & 76.69 & 82.13 & 10.00 & 1.75 & 133.31 & 545.19 & 259.31 \\
\hline 2100 & 502.94 & 28.63 & 81.00 & 3.38 & 1.75 & 534.75 & 537.75 & 244.31 \\
\hline$\%$ change & -39 & -63 & -1 & -66 & 0 & 301 & -1 & -6 \\
\hline \multicolumn{9}{|l|}{ Estrella } \\
\hline 2010 & $1,707.38$ & 235.94 & 200.75 & 0.00 & 0.56 & 1.81 & 121.94 & 102.13 \\
\hline 2100 & 896.88 & 111.31 & 199.06 & 0.00 & 0.56 & 11.44 & 669.44 & 480.81 \\
\hline$\%$ change & -47 & -53 & -1 & 0 & 0 & 531 & 449 & 371 \\
\hline \multicolumn{9}{|l|}{ Lower Butte } \\
\hline 2010 & 268.69 & 14.63 & 65.94 & 86.50 & 12.00 & 22.13 & 983.25 & 82.44 \\
\hline 2100 & 86.44 & 4.38 & 65.56 & 39.75 & 11.31 & 234.94 & $1,021.56$ & 82.00 \\
\hline$\%$ change & -68 & -70 & -1 & -54 & -6 & 962 & 4 & -1 \\
\hline \multicolumn{9}{|l|}{ Upper Stony } \\
\hline 2010 & 647.00 & 261.13 & 566.81 & 0.75 & 0.50 & 1.25 & 0.25 & 35.06 \\
\hline 2100 & 376.69 & 191.81 & 565.06 & 0.75 & 0.50 & 1.25 & 109.63 & 268.25 \\
\hline$\%$ change & -42 & -27 & 0 & 0 & 0 & 0 & 43,750 & 665 \\
\hline \multicolumn{9}{|l|}{ Upper Tule } \\
\hline 2010 & 175.31 & 126.25 & 304.63 & 0.06 & 0.56 & 1.25 & 5.94 & 4.81 \\
\hline 2100 & 128.44 & 83.31 & 302.88 & 0.06 & 0.56 & 41.69 & 31.88 & 29.75 \\
\hline$\%$ change & -27 & -34 & -1 & 0 & 0 & 3,235 & 437 & 518 \\
\hline
\end{tabular}

watersheds show consistent loss in habitat and water across all LULC scenarios-Suisun Bay, Lower Butte, Estrella River, and Lower Thomes-Sacramento (Fig. 4).

\section{Integrated urban development/climate effects on water supply}

Annual trends in recharge and runoff for the urbanized case study watersheds-Alameda Creek, Cosumnes, and Lower Butte-showed that greater peaks in runoff and lower recharge volumes become more common with increasing development. This pattern is most prevalent in the Alameda Creek watershed. For example, in 2053, recharge changes from 528 to 419 million $\mathrm{m}^{3}$ when accounting for future urbanization, and runoff changes from 568 to 716 million $\mathrm{m}^{3}$. Here, without urbanization, there are 66 years over the century where more water is delivered as recharge than runoff, while with future urbanization, this drops to 33 years (Fig. 5).

ANCOVA model results for each case study watershed showed that future development has a significant effect on the relationship between precipitation and the three dependent variables (recharge, runoff, and streamflow), with $\mathrm{R}^{2}$ ranging from 0.73 for some runoff models to over 0.90 for a majority of the models (Appendix 3, Table 1 in ESM). In the Alameda Creek and Lower Cosumnes watersheds, when future development is accounted for, recharge increases at a slower rate with precipitation than when future development is not included $\left(\mathrm{F}_{1,34}=20.41\right.$, $\mathrm{P}=0.000 ; \mathrm{F}_{1,34}=6.48, \mathrm{P}=0.016$ ). In the Lower Butte watershed, the rate of recharge with respect to precipitation does not change with urbanization, but recharge is significantly lower under the urban scenario than in the non-urban scenario for each precipitation value $\left(\mathrm{F}_{1,35}=7.84, \mathrm{P}=0.008\right)$. These 
(A) Future Development
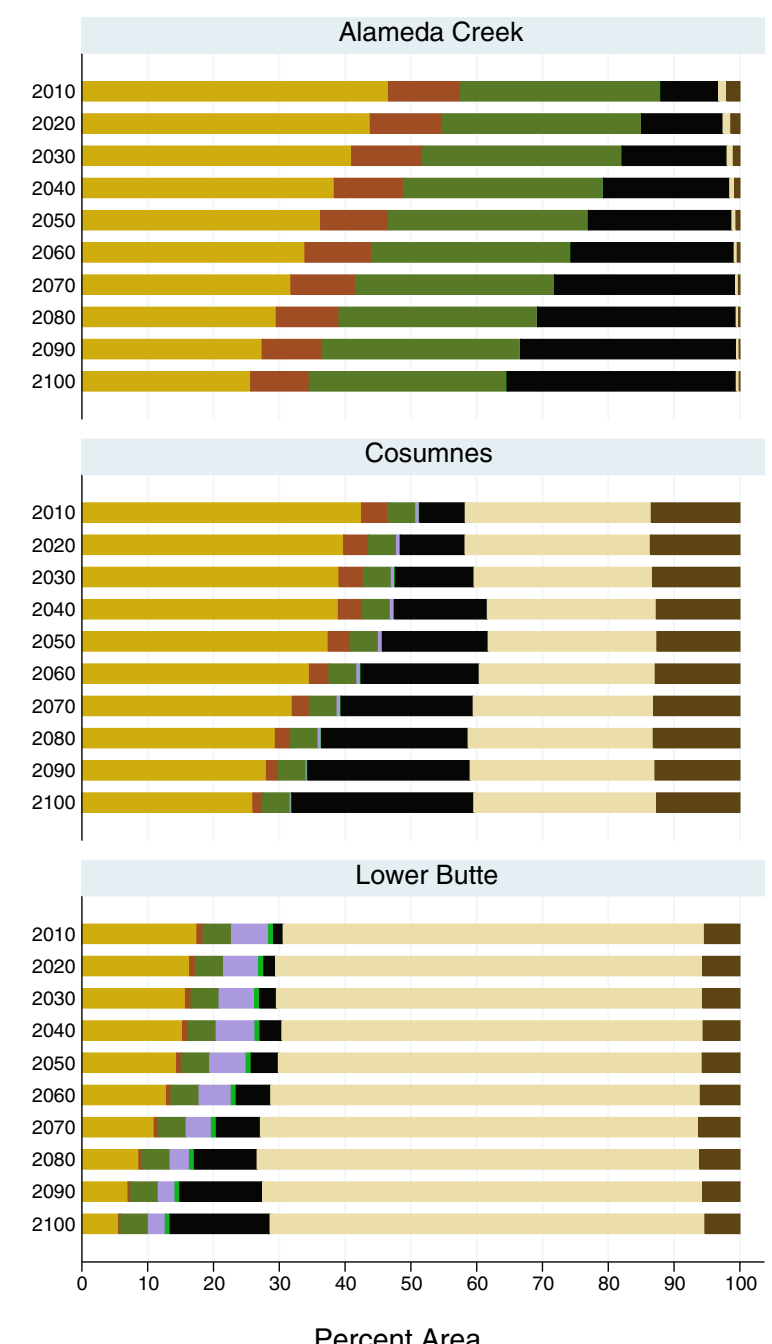

Percent Area

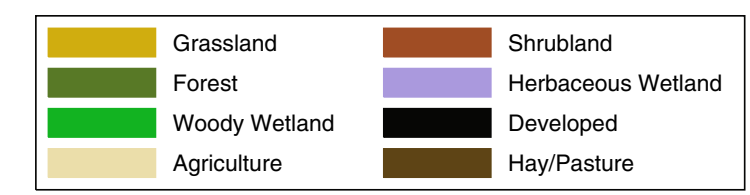

Graphs by Watershed
(B) Future Agriculture
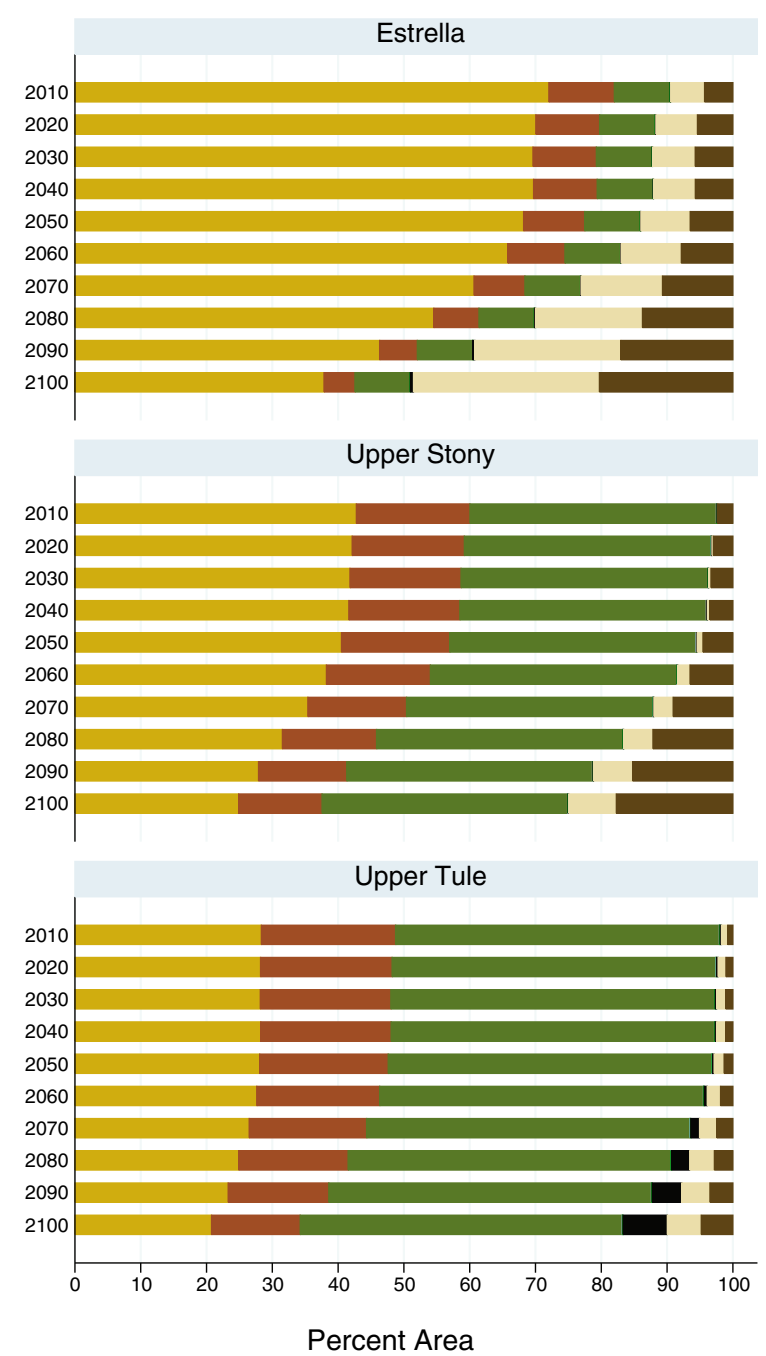

\begin{tabular}{|l|l|}
\hline Grassland & Shrubland \\
Forest & Herbaceous Wetland \\
Woody Wetland & Developed \\
Agriculture & Hay/Pasture \\
\hline
\end{tabular}

Graphs by Watershed

Fig. 3 Land use and land cover change by scenario and year as a percentage of watershed area for the $A 2$ scenario for a watersheds where future development is prevalent and $\mathbf{b}$ watersheds where future agriculture is prevalent

relationships are mirrored in the regression of runoff to precipitation, and streamflow to precipitation, where rates of runoff and streamflow increase with precipitation in a future urban scenario for Alameda Creek and Lower Cosumnes watersheds. In the Lower Butte, for each precipitation value, runoff and streamflow volume are higher under the urban scenario compared to the non-urban scenario (Appendix 3, Table 2 in ESM; Figs. 6, 7).

In the agriculture-dominated case study watersheds (Upper Stony, Estrella, and Upper Tule), there is not enough future urbanization to affect changes in recharge, runoff, and streamflow. However, plots of recharge and runoff to precipitation identify 


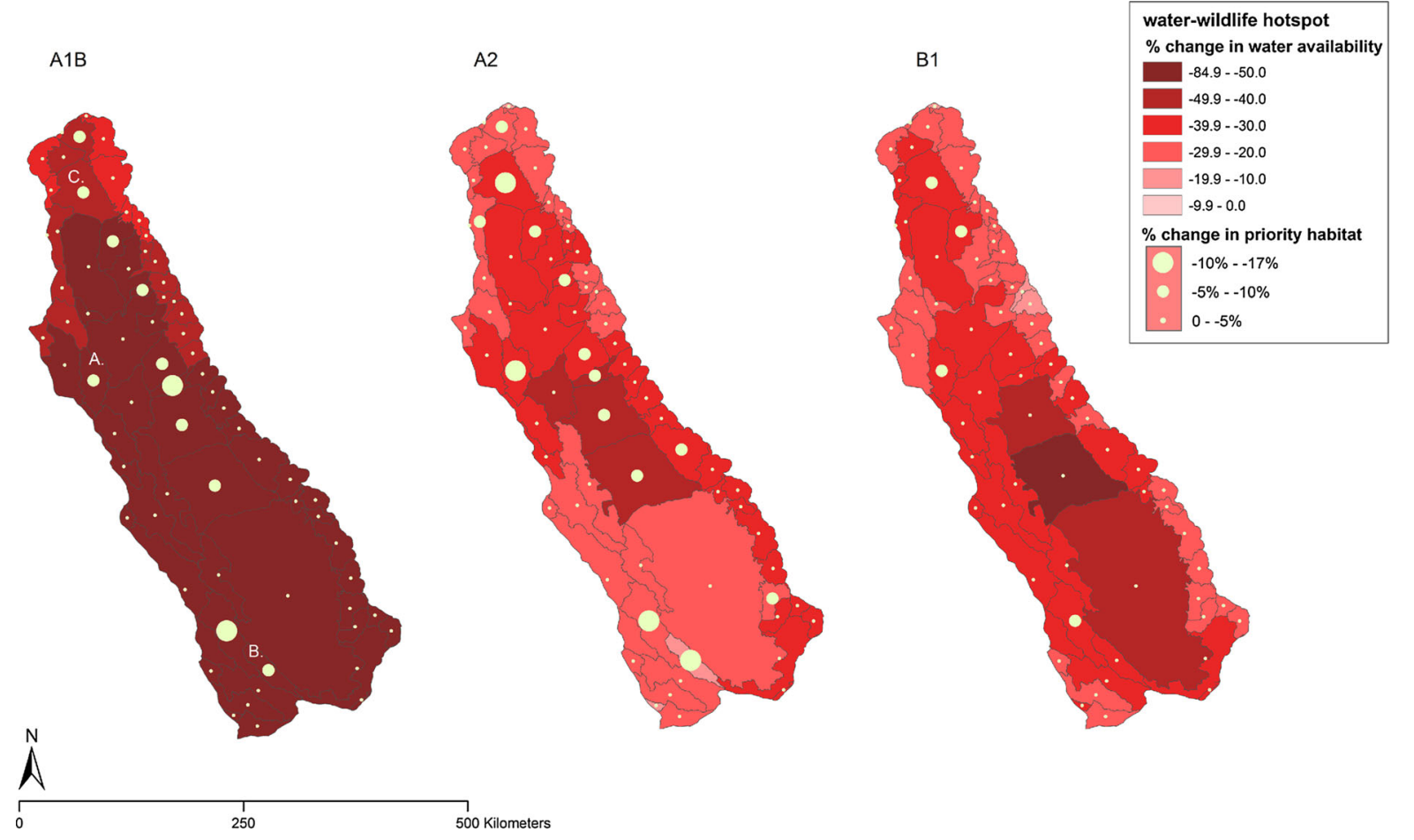

Fig. 4 Water-wildlife hotspots of change at 2100 for a warmer, dry climate model. These maps display percent change in water availability relative to the 1981-2010 climate period and percent change in proportion of watershed area with priority habitat. Priority habitat is defined as rangeland habitat in

precipitation thresholds where the dominant watershed hydrological process (the hydrological pathway through which more water flows) transitions from one to the other (Fig. 8). In general, processes transition from runoff-dominated to recharge dominated when conditions become dryer. For example, in the Upper Stony watershed, as projected precipitation lowers to $733 \mathrm{~mm}$, the dominant hydrological process switches from runoff to recharge. In the Alameda Creek watershed, without future urbanization, recharge is dominant at $517 \mathrm{~mm}$ of precipitation or lower, while under a future development scenario, there is no precipitation level where processes are dominated by recharge. In the Lower Cosumnes watershed, the watershed transitions from a recharge-dominated system to a runoff-dominated system for all levels of precipitation as a result of future development on deeper soils. This watershed would only become recharge dominated again at high precipitation levels $(1,300 \mathrm{~mm}$, Appendix 3, Table 3 in ESM). unprotected critical priority conservation areas mapped in the Rangeland Coalition focus area map (The Nature Conservancy 2007). A Suisun Bay watershed, B Carrizo Plain watershed, $C$ Lower Thomes-Sacramento watershed

\section{Discussion}

Habitat and soil carbon

The LULC change scenarios for California rangelands showed substantial losses in annual grassland habitat, compared to other habitats present in the region. This pattern is present at the focus area scale and the case study watershed scale. By 2100, grassland habitat across the focus area was reduced by $37 \%$ in the A2 scenario. This habitat loss drops to $22 \%$ by 2100 in the B1 scenario, which incorporates a more dense development pattern and one million acres of future conservation areas.

Land use change in all rangeland habitats compared to all priority habitats illustrates how different land use pressures affect different portions of the focus area. For example, across the focus area, cropland extent does not increase substantially over time, but within priority habitats, increase in cropland is a major cause of habitat loss (Fig. 2). These patterns of change 
Table 6 Soil organic carbon stocks (Tg C, top $20 \mathrm{~cm}$ ) on rangeland habitat and grasslands converted to other land uses for each scenario in 2010 and 2100, for the six case study watersheds and the California Rangeland Conservation Coalition focus area

\begin{tabular}{|c|c|c|c|c|c|c|c|}
\hline \multirow[t]{2}{*}{ Watershed } & \multirow{2}{*}{$\begin{array}{l}\text { Baseline } \\
2010 \text { SOC } \\
(\mathrm{Tg} \mathrm{C})\end{array}$} & \multicolumn{2}{|l|}{ A1B } & \multicolumn{2}{|l|}{ A2 } & \multicolumn{2}{|l|}{ B1 } \\
\hline & & $\begin{array}{l}2100 \mathrm{SOC} \\
(\mathrm{Tg} \mathrm{C})\end{array}$ & $\%$ converted & $\begin{array}{l}2100 \text { SOC } \\
(\mathrm{Tg} \mathrm{C})\end{array}$ & $\%$ converted & $\begin{array}{l}2100 \mathrm{SOC} \\
(\mathrm{Tg} \mathrm{C})\end{array}$ & $\%$ converted \\
\hline
\end{tabular}

\begin{tabular}{|c|c|c|c|c|c|c|c|}
\hline \multicolumn{8}{|c|}{ All rangeland habitat } \\
\hline Alameda Creek & 3.95 & 2.70 & 32 & 2.73 & 31 & 3.05 & 23 \\
\hline Cosumnes & 2.35 & 1.21 & 48 & 1.46 & 38 & 1.90 & 19 \\
\hline Estrella & 6.85 & 3.87 & 43 & 3.91 & 43 & 5.28 & \\
\hline Lower Butte & 1.74 & 0.80 & 54 & 0.67 & 61 & 2.58 & $-4 c$ \\
\hline Upper Stony & 2.42 & 1.97 & 19 & 1.67 & 31 & 1.95 & \\
\hline Upper Tule & 1.21 & 1.07 & 11 & 1.02 & 16 & 1.09 & \\
\hline Focus Area & 161.44 & 118.66 & 27 & 114.51 & 29 & 138.00 & \\
\hline \multicolumn{8}{|l|}{ Grassland habitat } \\
\hline Alameda Creek & 2.26 & 1.09 & 52 & 1.12 & 50 & 1.39 & \\
\hline Cosumnes & 2.04 & 0.97 & 52 & 1.23 & 40 & 1.63 & \\
\hline Estrella & 5.75 & 3.03 & 47 & 3.04 & 47 & 4.30 & \\
\hline Lower Butte & 0.85 & 0.37 & 57 & 0.27 & 68 & 0.50 & \\
\hline Upper Stony & 1.41 & 1.04 & 26 & 0.76 & 46 & 1.01 & \\
\hline Upper Tule & 0.45 & 0.34 & 24 & 0.31 & 30 & 0.36 & \\
\hline Focus Area & 99.77 & 63.76 & 36 & 60.91 & 39 & 76.35 & \\
\hline
\end{tabular}

Rangeland habitat in the land use-land cover (LULC) maps is defined as areas mapped as grassland, shrubland, forest, woody wetland, or herbaceous wetland

reflect LULC trends over the past 40 years. While urbanization has historically displaced aggregate farmlands, the actual amount of land in crops has not experienced a net decline, in fact, cropland increased in the region from 1973 to 2000 (Sleeter 2008; Sleeter et al. 2011).

Maintaining wildlife habitat on rangelands provides use and non-use benefits (Havstad et al. 2007; Kroeger et al. 2009; Shaw et al. 2011), which will be diminished if current conversion trends continue as projected. Additional research is needed to measure in monetary terms the potential economic costs associated with the loss of these benefits. To calculate these costs, baseline habitat values must first be developed, particularly for habitat on private land.

Land use distributions across the focus area in the LULC scenarios were driven by 26 possible biophysical and socioeconomic variables likely to be related to the presence of each LULC class (Appendix 2 in ESM). Some drivers of land use change, particularly fire effects, were not included in this modeling effort. In addition, the development class included a mixture of development densities. The use of a single development class would not affect land use projections when summarized at the watershed scale. However, the modeled effects of development on water supply may be biased toward greater hydrological responses when considering a single class.

The agricultural land use scenarios represent a wide range of future potential conditions, guided by the IPCC-SRES narrative storylines and IMAGE model outputs. The area of land allocated to cropland and hay/pasture was not constrained by natural resources availability, including water, though the spatial distribution of agriculture across the landscape was limited by biophysical factors including slope, soil quality, and temperature (Appendix 2 in ESM). Despite the limited physical controls on the agriculture scenarios, historical changes demonstrate that technological innovation can often remove certain barriers to cultivation. For example, in the western San Joaquin Valley, large areas of poorly drained soils have been cultivated, while in the Sierra foothills, orchards and vineyards have been planted despite the likelihood of soil loss associated with cultivation in these areas (Charbonneau and Kondolf 1993). Our scenarios (A2 

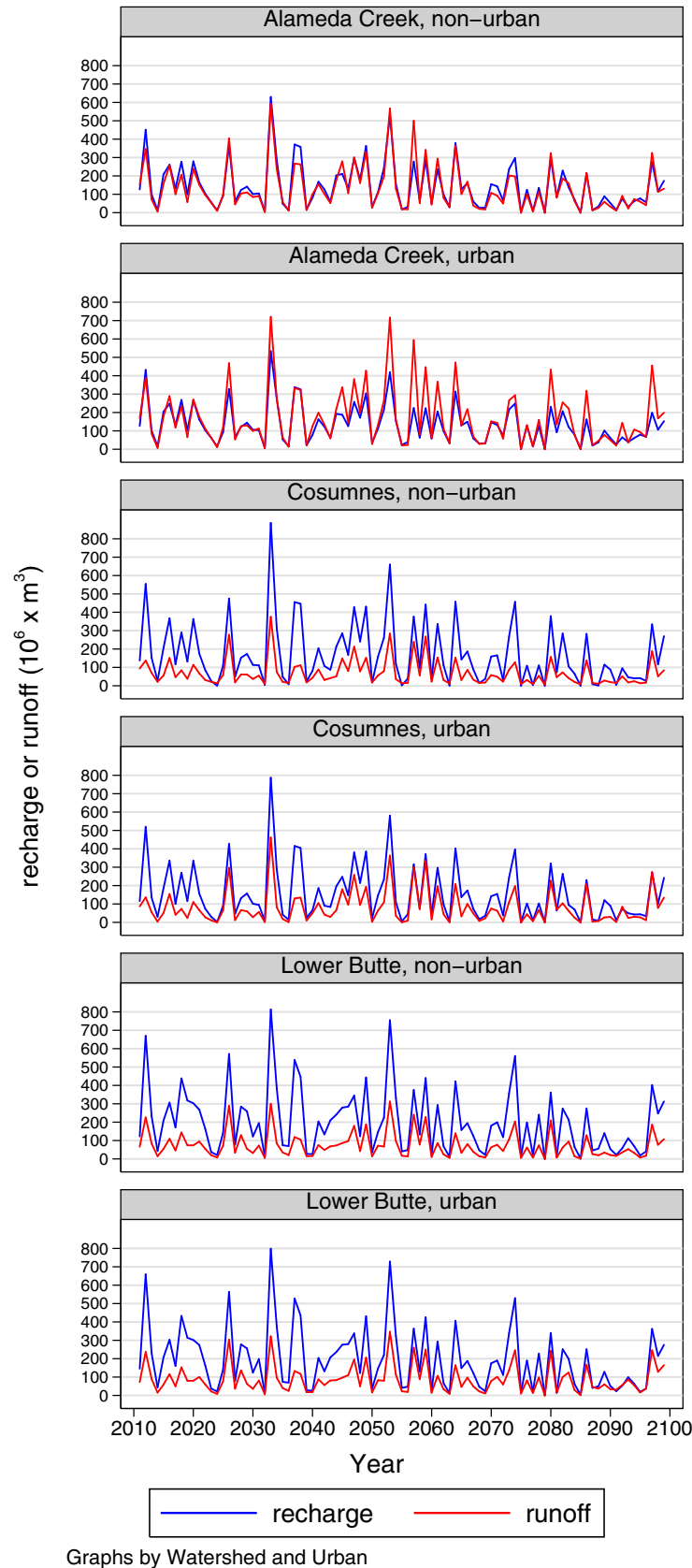

Fig. 5 Annual total recharge and runoff for three case study watersheds where future development is prevalent-Alameda Creek, Cosumnes, and Lower Butte-from 2010 to 2100 according to the GFDL A2 climate projection (warmer, dry) given no future urbanization and future urbanization

in particular) assume that agriculture will expand into marginally suited areas with the assumption that technological innovation would allow such a land use transition to be economically worthwhile for the landowner. To improve the scenarios, future work should consider linking the scenario downscaling model (Sleeter et al. 2012) with a hydrologic model capable of simulating ground and surface water budgets under a range of future climate conditions. In addition, while future cropland and hay/pasture are expected to be more extensive in the study region, and while climate can constrain agriculture (Melillo et al. 2014), more modeling on the combined effects of future agriculture and climate change on water supply is needed.

Grasslands within the Central Valley and surrounding foothills represent a substantial carbon poolapproximately $100 \mathrm{Tg}$ SOC in the top $20 \mathrm{~cm}$ of soil. Up to $39 \%$ of this SOC is subject to conversion by 2100. Little research is available on the effects of land conversion on grassland SOC in California. Typical construction practices have been found to degrade soil by surface soil removal and subsoil compaction, leading to loss of total soil carbon in the top $10 \mathrm{~cm}$ by approximately $35 \%$ (Chen et al. 2013). However, outcomes for SOC after grassland conversion to urban land uses are uncertain. For example, soil $\mathrm{C}$ can increase when converted to urban green spaces or lawns (Golubiewski 2006). Also, tillage of lands for cropland often leads to rapid declines in soil carbon (Lal 2002), though total ecosystem carbon may increase if grasslands are replaced by orchards (Kroodsma and Field 2006).

\section{Water supply}

By combining changes in priority habitat and water supply at the watershed scale, patterns across the focus area emerge, which are persistent across scenarios (Fig. 4). In some watersheds, loss of habitat due to land use change overlaps with loss of water supply due to climate change. Watersheds with greater loss in priority habitat are relatively prevalent in the A2 and A1B scenarios, though four watersheds with relatively high habitat loss remain in the B1 conservation scenario. For warmer, dry climate projections, all watersheds would experience loss in water supply, though portions of the central San Joaquin Valley (central, southern portion of the focus area) show consistently greater loss in water supply across projections.

Variability in precipitation across climate projections creates uncertainty in the amount of water 
Fig. 6 Regression of recharge or runoff to precipitation for three case study watersheds where future development is prevalent-Alameda Creek, Cosumnes, and Lower Butte. Regressions are provided assuming a no future urbanization (left column) and b future urbanization (right column). Each point represents a 4-year average of values for a given climate projection. Four-year averages were calculated for 2003-2006, 2037-2040, 2067-2070, and 2096-2099
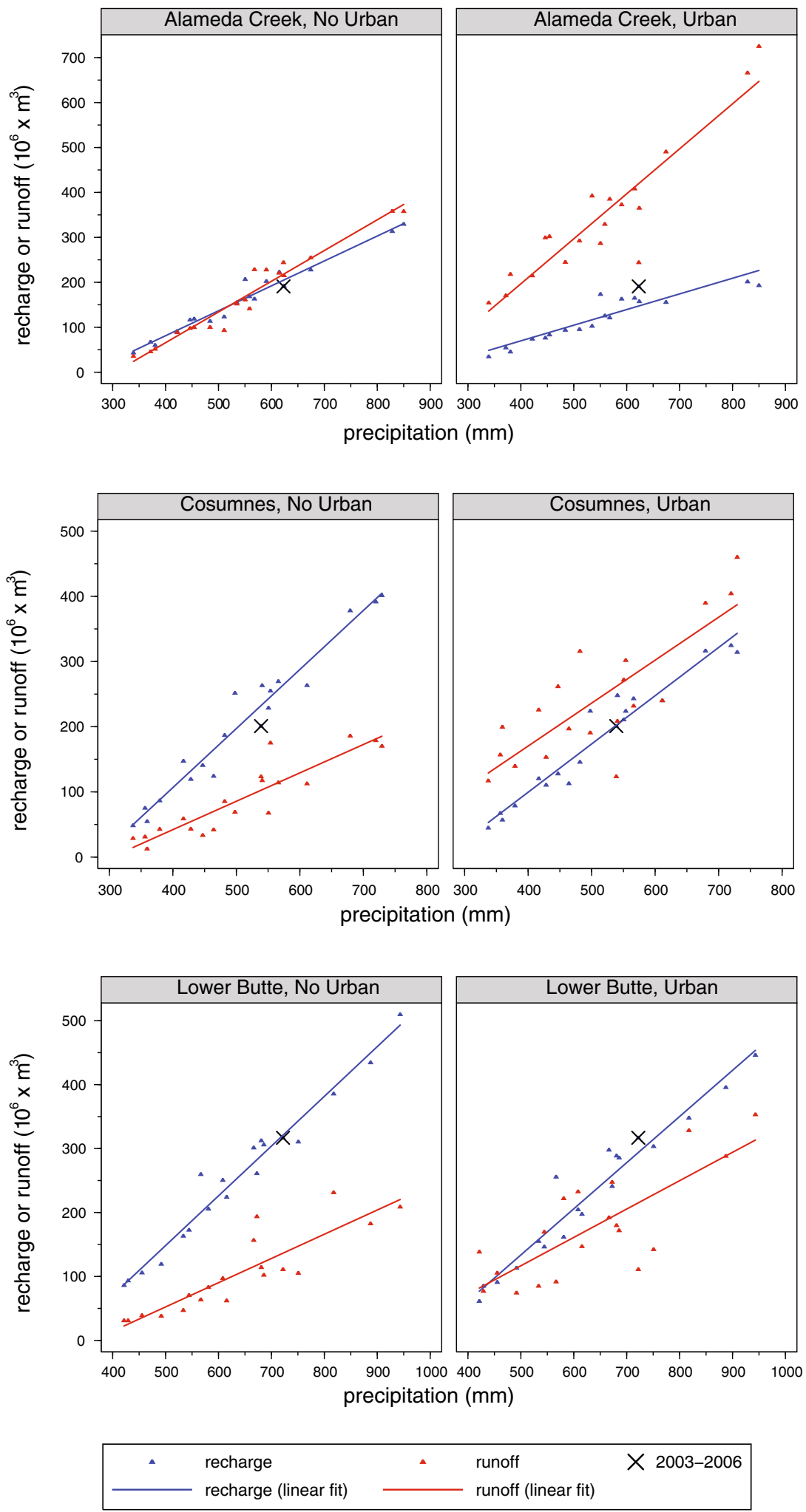

Graphs by Watershed and Urban 

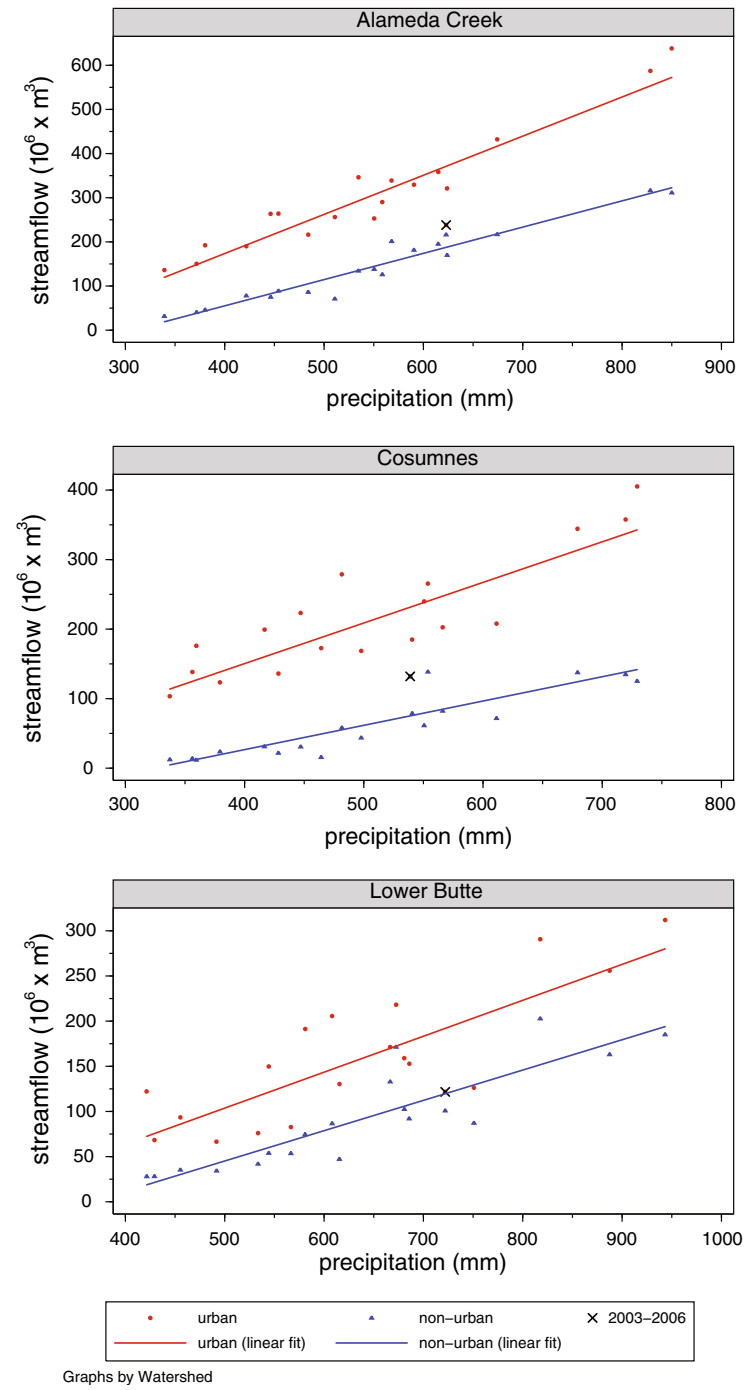

Fig. 7 Regression of streamflow to precipitation assuming no future urbanization and future urbanization for three case study watersheds where future development is prevalent-Alameda Creek, Cosumnes, and Lower Butte. Each point represents a 4 -year average of values for a given climate projection. Fouryear averages were calculated for 2003-2006, 2037-2040, 2067-2070, and 2096-2099

available in the future. New ensemble models show California becoming slightly more wet by 2100 (Flint and Flint 2014). Despite this overall trend, models also show an increase in extreme events and longer periods of droughts (Polade et al. 2014). Our model outputs show that recharge processes dominate in dry years, when runoff volumes fall below recharge volumes. More development in a watershed lowers the precipitation level at which recharge volumes exceed runoff (Appendix 3,
Table 3 in ESM). As a result, urban development combined with periods of drought reduces the opportunity for recharge, especially if development occurs on deep soils.

Annual projections for urban watersheds further demonstrate how development and changing climate may affect water supply. For the warmer/dry GFDL A2 scenario, recharge rates decline over the century, and with future urbanization, the volume of water supplied as recharge is further reduced (Fig. 5). In addition, there are projected increases in high flows as a result of urbanization, with implications for flooding, erosion, and habitat degradation.

These results support the need for resilience in watersheds against extreme events such as drought, and demonstrate the role of open rangelands in capturing water and reducing runoff. This need for resilience can be addressed by climate-smart land use planning that takes recharge areas into account, which will provide opportunities for water storage and increase water supply in dry years, especially in groundwater-dependent watersheds. Sustaining groundwater supply will provide water for human use, and will also support certain types of aquatic, terrestrial, and coastal ecosystems that rely on subsurface stores of water to function or persist (Howard and Merrifield 2010).

As with habitat valuation, current baseline cost information relating to groundwater recharge infrastructure is needed to provide a monetary estimate of the expected impacts of climate and land use change on recharge rates. A thorough economic analysis would depend on the type of integrated water management strategies adopted to deal with projected lower recharge (and higher runoff) rates in the future. Future modeling could be conducted to estimate potential costs of water management infrastructure adaptations based on changes in watershed water supply (Connell-Buck et al. 2011; Medellín-Azuara et al. 2011).

These results on watershed planning and management have been translated to land owners and land managers through an outreach program led by Defenders of Wildlife. Workshops with local Resource Conservation Districts in particular have sought to link applications of model outputs to on-theground decision making. Managers have identified the utility of recharge and runoff projections for zoning decisions. In addition, results have emphasized the 
Fig. 8 Regression of recharge or runoff to precipitation for three case study watersheds where future agriculture is prevalent. Each point represents a 4-year average of values for a given climate projection. Four-year averages were calculated for 2003-2006, 2037-2040,

2067-2070, and 2096-2099
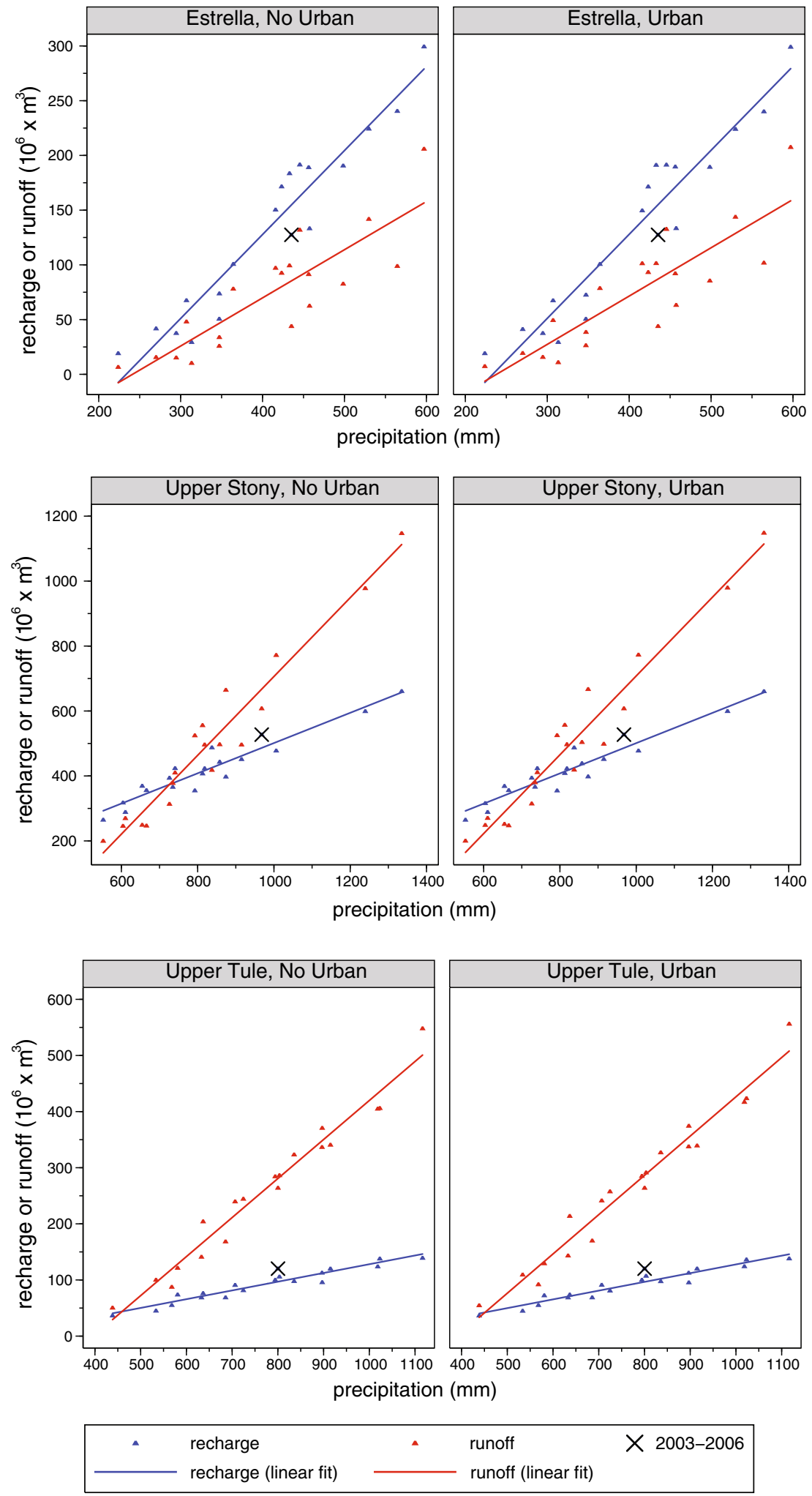

Graphs by Watershed and Urban 
need to maintain a permeable watershed in light of climate change, and to protect soils to improve productivity and maintain water supply. Model outputs and a synthesis of model results have been made available through an online visualization tool hosted by the California Climate Commons (http://climate. calcommons.org/aux/rangeland/index.html).

\section{Conclusion}

A suite of analyses on future integrated scenarios for rangelands in California's Central Valley and surrounding foothills show that rangeland conversion and climate change will alter the provision of ecosystem services provided by California rangelands. Grassland habitat loss could reach $37 \%$ by 2100 . In priority habitats, this loss is predominantly a result of agricultural expansion. Grasslands in the Rangeland Coalition focus area store approximately $100 \mathrm{Tg}$ SOC in the top $20 \mathrm{~cm}$, representing a substantial social benefit, and almost $40 \%$ is subject to conversion. Variability in precipitation across climate projections creates uncertainty in the amount of water available in the future but most scenarios project that the dry season will be extended and storage will be necessary, either above or belowground. Urban development combined with periods of drought reduces the opportunity for recharge. Results show the need for climate-smart land use planning that recognizes the role of rangelands as providers of ecosystem services such as maintaining recharge areas that can help maintain water supply in dry years. Given projections for future agricultural expansion at the expense of rangelands, more research is needed on feedbacks between land use change and water availability. Further research on baseline water infrastructure and habitat costs and benefits is needed to value in monetary terms market and non-market impacts on rangeland ecosystem goods and services due to climate and land use change. This information will allow us to better determine the value of the ecosystem services provided by California rangelands, as well as the change in value resulting from rangeland conversion.

Acknowledgments We thank The Nature Conservancy for use of the critical priority habitat map for the California Rangeland Conservation Coalition Focus Area. We thank Adam McClure for data processing and analysis; the Defenders of Wildlife for outreach to the Coalition network; the California
Rangeland Conservation Coalition and several of its signatories for providing feedback throughout the project; and also ranchers Virginia Coelho, Mel Thompson, Tracy Schohr, Pete Craig, Todd Swickard, Al Medvitz, Cari Rivers, and Darrel Sweet for their input in developing the integrated scenarios. The project was funded by the California Landscape Conservation Cooperative and the USGS LandCarbon Project. Any use of trade, firm, or product names is for descriptive purposes only and does not imply endorsement by the U.S. Government.

Open Access This article is distributed under the terms of the Creative Commons Attribution License which permits any use, distribution, and reproduction in any medium, provided the original author(s) and the source are credited.

\section{References}

Ash A, Thornton P, Stokes C, Togtohyn C (2012) Is proactive adaptation to climate change necessary in grazed rangelands? Rangel Ecol Manag 65(6):563-568

Bierwagen BG, Theobald DM, Pyke CR, Choate A, Groth P, Thomas JV, Morefield P (2010) National housing and impervious surface scenarios for integrated climate impact assessments. Proc Natl Acad Sci 107(49):20887-20892

Bliss NB (2003) Soil organic carbon on lands of the Department of the Interior, USGS open-file report 03-304. U.S. Geological Survey, Reston, VA. http://egsc.usgs.gov/isb/pubs/ openfile/OFR03-304.pdf. Accessed January 2013

Booker K, Huntsinger L, Bartolome JW, Sayre NF, Stewart W (2013) What can ecological science tell us about opportunities for carbon sequestration on arid rangelands in the United States? Global Environ Change-Hum Policy Dimens 23(1):240-251

Brown J, MacLeod N (2011) A site-based approach to delivering rangeland ecosystem services. Rangel J 33(2):99-108

Brunson MW, Huntsinger L (2008) Ranching as a conservation strategy: can old ranchers save the new west? Rangel Ecol Manag 61(2):137-147

California Department of Forestry and Fire Protection Fire and Resource Assessment Program (2003) Changing California: forest and range 2003 assessment. California Department of Forestry and Fire Protection, Sacramento. http:// frap.fire.ca.gov/assessment/index.php. Accessed February 2014

California Department of Forestry and Fire Protection Fire and Resource Assessment Program (2010) California's Forests and Rangelands: 2010 Assessment. California Department of Forestry and Fire Protection, Sacramento. http://frap. fire.ca.gov/assessment/index.php. Accessed February 2014

Cameron DR, Marty J, Holland RF (2014) Whither the rangeland?: protection and conversion in california's rangeland ecosystems. PLoS One 9(8):e103468

Charbonneau R, Kondolf GM (1993) Land use change in California, USA: nonpoint source water quality impacts. Environ Manag 17(4):453-460

Chen Y, Day SD, Wick AF, Strahm BD, Wiseman PE, Daniels WL (2013) Changes in soil carbon pools and microbial biomass from urban land development and subsequent 
post-development soil rehabilitation. Soil Biol Biochem 66:38-44

Connell-Buck C, Medellín-Azuara J, Lund J, Madani K (2011) Adapting California's water system to warm vs. dry climates. Clim Change 109(1):133-149

Daly C, Halbleib M, Smith JI, Gibson WP, Doggett MK, Taylor GH, Curtis J, Pasteris PP (2008) Physiographically sensitive mapping of climatological temperature and precipitation across the conterminous United States. Int J Climatol 28(15):2031-2064

de Chazal J, Rounsevell MDA (2009) Land-use and climate change within assessments of biodiversity change: a review. Global Environ Change-Hum Policy Dimens 19(2):306-315

Flint L, Flint A (2012) Downscaling future climate scenarios to fine scales for hydrologic and ecological modeling and analysis. Ecol Process 1(1):2

Flint L, Flint A, Thorne J, Boynton R (2013) Fine-scale hydrologic modeling for regional landscape applications: the California Basin characterization model development and performance. Ecol Process 2(1):25

Flint LE, Flint AL (2014) California Basin characterization model: a dataset of historical and future hydrologic response to climate change. U.S. Geological Survey Dataset Release. doi:10.5066/F76T0JPB

Follett RF, Kimble JM, Lal R (2001) The potential of US. grazing lands to sequester carbon and mitigate the greenhouse effect. CRC, Boca Raton

Gaman T, Firman J (2006) Oaks 2040. California Oaks Foundation, Oakland. http://www.californiaoaks.org/ Oaks2040. Accessed February 2014

Garrison GA, Bjugstad AJ, Duncan DA, Lewis ME, Smith DR (1977) Vegetation and environmental features of forest and range ecosystems, vol 475., Agriculture HandbookDepartment of Agriculture Forest Service, Washington, DC, p 168

Golubiewski NE (2006) Urbanization increases grassland carbon pools: effects of landscaping in Colorado's front range. Ecol Appl 16(2):555-571

GreenInfo Network (2011) California protected areas database version 1.7. http://www.calands.org/data. Accessed January 2012

Havstad KM, Peters DPC, Skaggs R, Brown J, Bestelmeyer B, Fredrickson E, Herrick J, Wright J (2007) Ecological services to and from rangelands of the United States. Ecol Econ 64(2):261-268

He M, Hogue TS (2012) Integrating hydrologic modeling and land use projections for evaluation of hydrologic response and regional water supply impacts in semi-arid environments. Environ Earth Sci 65(6):1671-1685

Herrick JE, Brown JR, Bestelmeyer BT, Andrews SS, Baldi G, Davies J, Duniway M, Havstad KM, Karl JW, Karlen DL, Peters DPC, Quinton JN, Riginos C, Shaver PL, Steinaker D, Twomlow S (2012) Revolutionary land use change in the 21st century: is (rangeland) science relevant? Rangel Ecol Manag 65(6):590-598

Homer C, Dewitz J, Fry J, Coan M, Hossain N, Larson CR, Herold N, McKerrow A, van Driel N, Wickham J (2007) Completion of the 2001 national land cover database for the conterminous United States. Photogrammetr Eng Remote Sens 73(4):337-341
Howard J, Merrifield M (2010) Mapping groundwater dependent ecosystems in California. PLoS ONE 5(6): e11249

Jantz PA, Preusser BFL, Fujikawa JK, Kuhn JA, Bersbach CJ, Gelbard JL, Davis FW (2007) Regulatory protection and conservation. In: Stromberg MR, Corbin JD, D'Antonio CM (eds) California grasslands: ecology and management. University of California Press, Berkeley, pp 297-318

Jongsomjit D, Stralberg D, Gardali T, Salas L, Wiens J (2013) Between a rock and a hard place: the impacts of climate change and housing development on breeding birds in California. Landscape Ecol 28(2):187-200

Kroeger T, Casey F, Alvarez P, Cheatum M, Tavassoli L (2009) An economic analysis of the benefits of habitat conservation on California rangelands. Conservation economics white paper. Defenders of Wildlife, Washington, DC

Kroodsma DA, Field CB (2006) Carbon sequestration in California agriculture, 1980-2000. Ecol Appl 16(5):1975-1985

Lal R (2002) Soil carbon dynamics in cropland and rangeland. Environ Pollut 116(3):353-362

Liu S, Liu J, Young CJ, Werner JM, Wu Y, Li Z, Dahal D, Oeding J, Schmidt GL, Sohl TL, Hawbaker TJ, Sleeter BM (2012) Chapter 5. Baseline carbon storage, carbon sequestration, and greenhouse-gas fluxes in terrestrial ecosystems of the Western United States. In: Zhu Z, Reed $\mathrm{BC}$ (eds) Baseline and projected future carbon storage and greenhouse-gas fluxes in ecosystems of the Western United States. U.S. Geological Survey Professional Paper 1797, pp 1-20

Loveland TR, Sohl TL, Stehman SV, Gallant AL, Sayler KL, Napton DE (2002) A strategy for estimating the rates of recent United States land-cover changes. Photogrammetr Eng Remote Sens 68(10):1091-1099

Major J (1977) California climate in relation to vegetation. In: Barbour MG, Major J (eds) Terrestrial vegetation of California. Wiley, New York

Medellín-Azuara J, Howitt R, MacEwan D, Lund J (2011) Economic impacts of climate-related changes to California agriculture. Clim Change 109(1):387-405

Meehl GA, Covey C, Taylor KE, Delworth T, Stouffer RJ, Latif M, McAveney B, Mitchell JFB (2007) The WCRP CMIP3 multimodel dataset: a new era in climate change research. Bull Am Meteorol Soc 88(9):1383-1394. doi:10.1175/ BAMS-88-9-1383

Melillo JM, Richmond TC, Yohe GW (eds) (2014) Climate change impacts in the United States: the third national climate assessment. U.S. Global Change Research Program

Merenlender A, Deitch M, Feirer S (2008) Decision support tool seeks to aid stream-flow recovery and enhance water security. Calif Agric 62(4):148-155

Millennium Ecosystem Assessment (2005) Ecosystems and human well-being: synthesis. Island, Washington, DC

Moss RH, Edmonds JA, Hibbard KA, Manning MR, Rose SK, van Vuuren DP, Carter TR, Emori S, Kainuma M, Kram T, Meehl GA, Mitchell JFB, Nakicenovic N, Riahi K, Smith SJ, Stouffer RJ, Thomson AM, Weyant JP, Wilbanks TJ (2010) The next generation of scenarios for climate change research and assessment. Nature 463(7282):747-756

Nakicenovic N, Swart R (eds) (2000) Special report on emissions scenarios: a special report of working group III of the 
intergovernmental panel on climate change. Cambridge University Press, Cambridge, UK

Natural Resources Conservation Service (2006) U.S. general soil map (SSURGO/STATSGO2). http://www.ftw.nrcs. usda.gov/stat_data.html, http://soils.usda.gov/survey/ geography/statsgo/description.html. Accessed October 2, 2014

Polade SD, Pierce DW, Cayan DR, Gershunov A, Dettinger MD (2014) The key role of dry days in changing regional climate and precipitation regimes. Nat Sci Rep 4:4364

Potthoff M, Jackson LE, Steenwerth KL, Ramirez I, Stromberg MR, Rolston DE (2005) Soil biological and chemical properties in restored perennial grassland in California. Restor Ecol 13(1):61-73

Quinn GP, Keough MJ (2002) Experimental design and data analysis for biologists. Cambridge University Press, Cambridge

Radeloff VC, Nelson E, Plantinga AJ, Lewis DJ, Helmers D, Lawler JJ, Withey JC, Beaudry F, Martinuzzi S, Butsic V, Lonsdorf E, White D, Polasky S (2012) Economic-based projections of future land use in the conterminous United States under alternative policy scenarios. Ecol Appl 22(3):1036-1049

SAS Institute Inc. (2002-2010) SAS 9.3. Cary, NC

Scanlon BR, Reedy RC, Stonestrom DA, Prudic DE, Dennehy KF (2005) Impact of land use and land cover change on groundwater recharge and quality in the southwestern US. Glob Change Biol 11(10):1577-1593

Shaw MR, Pendleton L, Cameron DR, Morris B, Bachelet D, Klausmeyer K, MacKenzie J, Conklin DR, Bratman GN, Lenihan J, Haunreiter E, Daly C, Roehrdanz PR (2009) The impact of climate change on California's ecosystem services. California Energy Commission Scenarios Report. CEC-500-2009-025-D

Shaw MR, Pendleton L, Cameron DR, Morris B, Bachelet D, Klausmeyer K, MacKenzie J, Conklin DR, Bratman GN, Lenihan J, Haunreiter E, Daly C, Roehrdanz PR (2011) The impact of climate change on California's ecosystem services. Climatic Change 109(1):465-484

Silver WL, Ryals R, Eviner V (2010) Soil carbon pools in California's annual grassland ecosystems. Rangel Ecol Manag 63(1):128-136

Sleeter BM (2008) Late 20th century land change in the Central California Valley ecoregion. Calif Geographer 48:27-60

Sleeter BM, Wilson TS, Soulard CE, Liu J (2011) Estimation of late twentieth century land-cover change in California. Environ Monit Assess 173(1-4):251-266

Sleeter BM, Sohl TL, Bouchard MA, Reker RR, Soulard CE, Acevedo W, Griffith G, Sleeter RR, Auch RF, Sayler KL, Prisley S, Zhu Z (2012) Scenarios of land use and land cover change in the conterminous United States: utilizing the special report on emission scenarios at ecoregional scales. Glob Environ Change 22(4):896-914

Society for Range Management (1998) Glossary of terms used in range management (4th edn). https://globalrangelands. org/rangelandswest/glossary/i?order=title \&sort=desc \& term=. Accessed October 2, 2014 (edited by Glossary Update Task Group, Thomas E. Bedell, Chairman)

Sohl TL, Sleeter BM, Zhu Z, Sayler KL, Bennett S, Bouchard M, Reker R, Hawbaker T, Wein A, Liu S, Kanengieter R, Acevedo W (2012) A land-use and land-cover modeling strategy to support a national assessment of carbon stocks and fluxes. Appl Geogr 34:111-124

Sohl TL, Sayler KL, Bouchard MA, Reker RR, Friesz AM, Bennett SL, Sleeter BM, Sleeter RR, Wilson T, Soulard C, Knuppe M, Van Hofwegen T (2014) Spatially explicit modeling of 1992 to 2100 land cover and forest stand age for the conterminous United States. Ecol Appl 24(5): $1015-1036$

Soulard CE, Wilson TS (2015) Recent land-use/land-cover change in the Central California Valley. J Land Use Sci 10(1):59-80

StataCorp LP (1985-2011) Stata/SE 12.1. StataCorp LP, College Station

State of California Department of Finance (2013) Report P-1 (County): State and County Total Population Projections, 2010-2060. Sacramento. http://www.dof.ca.gov/research/de mographic/reports/projections/p-1/. Accessed January 2014

Strengers B, Leemans R, Eickhout B, Vries B, Bouwman L (2004) The land-use projections and resulting emissions in the IPCC SRES scenarios as simulated by the IMAGE 2.2 model. GeoJournal 61(4):381-393

The Nature Conservancy (2007) California rangeland conservation coalition biological prioritization of rangelands: approach and methods. http://www.carangeland.org/ images/Appraoch_and_Methods.pdf. Accessed January 2012

Theobald DM (2005) Landscape patterns of exurban growth in the USA from 1980 to 2020. Ecol Soc 10(1):32

U.S. Endowment for Forestry and Communities (2011) National conservation easement database. http:// conservationeasement.us/. Accessed January 2012

U.S. Environmental Protection Agency (2009) Land-use scenarios: national-scale housing-density scenarios consistent with climate change storylines (final report). EPA/600/R-08/076f. Environmental Protection Agency, Washington, DC

U.S. Environmental Protection Agency (2013) Primary distinguishing characteristics of level III ecoregions of the continental United States. http://www.epa.gov/wed/pages/ ecoregions/level_iii_iv.htm. Accessed March 2014

Vogelmann JE, Howard SM, Yang L, Larson CR, Wylie BK, van Driel N (2001) Completion of the 1990s national land cover data set for the conterminous United States. Photogrammetr Eng Remote Sens 67(6):650-652

Vuuren D, Edmonds J, Kainuma M, Riahi K, Thomson A, Hibbard K, Hurtt G, Kram T, Krey V, Lamarque J-F, Masui T, Meinshausen M, Nakicenovic N, Smith S, Rose S (2011) The representative concentration pathways: an overview. Clim Change 109(1-2):5-31

Weltz MA, Jolley L, Goodrich D, Boykin K, Nearing M, Stone J, Guertin P, Hernandez M, Spaeth K, Pierson F, Morris C, Kepner B (2011) Techniques for assessing the environmental outcomes of conservation practices applied to rangeland watersheds. J Soil Water Conserv 66(5):154A$162 \mathrm{~A}$

Zhu Z, Reed BC (2012) Baseline and projected future carbon storage and greenhouse-gas fluxes in ecosystems of the Western United States. U.S. Geological Survey Professional Paper 1797. http://pubs.usgs.gov/pp/1797/. Accessed February 2014 